\title{
Research Paper \\ Predicting Self-Regulated Learning Based on Students' Motivational Beliefs, Intelligence Beliefs, and Perception of Classroom Atmosphere in Students at Gifted Schools: The Mediating Role of Self-Efficacy and Achievement Goals
}

\author{
Mahsa Jourabi Asrejadid ${ }^{1}$, Mansure Shahriari Ahmadi ${ }^{* 2}$, Mahdiyeh Salehi ${ }^{2}$, Mahnaz Estaki \\ 1. Ph.D. Student of Psychology, Department of Psychology, Central Tehran Branch, Islamic Azad University, Tehran, Iran \\ 2. Assistant Professor, Department of Psychology, Central Tehran Branch, Islamic Azad University, Tehran, Iran
}

\begin{abstract}
Citation: Jourabi Asrejadid M, Shahriari Ahmadi M, Salehi M, Estaki M. Predicting self-regulated learning based on students' motivational beliefs, intelligence beliefs, and perception of classroom atmosphere in students at gifted schools: the mediating role of self-efficacy and achievement goals. J Child Ment Health. 2021; 8 (1):155-174.
\end{abstract}

URL: http://childmentalhealth.ir/article-1-1050-en.html
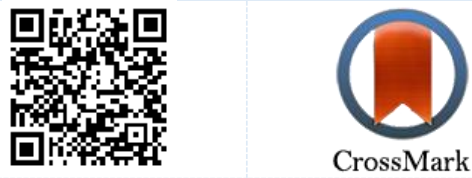

$10.29252 / \mathrm{jcmh} .8 .1 .12$ 0.1001.1.24233552.1400.8.1.8.7
A R T I C L E I N F O

\section{Keywords:}

Self-regulated learning, motivational beliefs, intelligence beliefs, perception of classroom atmosphere,

self-efficacy, achievement goals

Received: 12 Aug 2020 Accepted: 19 Nov 2020 Available: 18 Jun 2021

\section{A B S T R A C T}

Background and Purpose: Self-regulated learning has a very important role in students' education and learning processes and academic self-efficacy and achievement goals are effective factors in developing this ability. In this regard, the purpose of this study was examining a prediction model of self-regulated learning based on students' motivational beliefs, intelligence beliefs, and perception of classroom atmosphere while considering the mediating role of self-efficacy and achievement goals in students at Iranian gigted schools.

Method: The present study was a descriptive correlational study. The statistical population included all eighth grade high school students at gifted schools in Tehran in 2020-21 school year. Four hundred students were selected through cluster random sampling. The research tools consisted of the General Self-Efficacy Scale (GSES) (Sherer et al., 1982), Motivational Strategies for Learning Questionnaire (MSLQ) (Pintrich et al., 1990), Perceptions of Classroom Atmosphere Questionnaire (Rovy, 2002), Intelligence Beliefs Questionnaire (Abdolfattah and Yiths, 2006), and Achievement Goals Questionnaire (Midgley, 1988). The collected data were analyzed through structural equation modeling (SEM) technique.

Results: According to the results, the variables of achievement goals, self-efficacy, intelligence beliefs, motivational beliefs, and perception of classroom atmosphere had a positive and significant relationship with self-regulated learning $(\mathrm{P}<0.01)$. Moreover, the findings confirmed the mediating role of self-efficacy in the relationship between self-regulated learning and motivational beliefs and perception of classroom atmosphere and the mediating role of achievement goals in the relationship between self-regulated learning and motivational beliefs.

Conclusion: The results showed the desirable status of the fit indices of the research model. Furthermore, motivational beliefs variable had both direct and indirect effects on self-regulated learning variable.

* Corresponding author: Mansure Shahriari Ahmadi, Assistant Professor, Department of Psychology, Central Tehran Branch, Islamic Azad University, Tehran, Iran.

E-mail: Mansure_shahriari@yahoo.com

Tel: (+98) 2144600200

2476-5740/ ( 2021 The Authors. This is an open access article under the CC BY-NC-ND license

(https://creativecommons.org/licenses/by-nc-nd/4.0/). 


\section{Extended Abstract}

\section{Introduction}

Learning is one of the most important and interesting subjects for psychologists who attempt to understand the complex dimensions of learning (1). Zimmerman, as one of the theorists of the cognitive-social theory, defined the self-regulatury learning strategies as a type of learning, in which the learners personally start and direct their endeavors in acquiring skills and knowledge instead of relying on teachers, parents, and other educational factors (4). However, the results of the previous studies have indicated that motivation and motivational variables have a direct and significant effect on the learners' cognitive efficiency. (9, 28, and 17).

One of the variables related to learning selfregulation is self-efficacy (13). Self-efficacy is an individual's confidence in their ability to control their thoughts, feelings, and activities (16). Furthermore, goal orientation describes motivations based on which a goal is pursued and emphasizes a person's purpose and intention to make progress in their tasks (18). Achievement goal represent a comprehensive semantic system of situations or contexts that have cognitive, emotional, and behavioral consequences that learners use to interpret their actions $(10,11,17$, \& 19).

Dweck's social cognitive approach, which has attracted considerable attention, is another approach concerned with determining the relationship of the cognitive and motivational factors with students' learning. The key concepts in this approach include intelligence beliefs and achievement goals (quoted in 29). According to Dweck, intelligence beliefs are marginal factors in a successful behavior (32). On the other hand, the classroom atmosphere is defined as the qualitative properties of a class and influences the attitudes, behaviors, and performance improvements of individuals who are in contact with school. (34).

In this regard, the purpose of this study was examining a prediction model of self-regulated learning based on students' motivational beliefs, intelligence beliefs, and perception of classroom atmosphere while considering the mediating role of self-efficacy and achievement goals in students at Iranian gigted schools.

\section{Method}

The present study was a descriptive correlational study. The structural equation modeling (SEM) was used to examine the relationship between the research variables. The statistical population included all eighth grade high school students at gifted schools in Tehran in 2020-21 school year. Four hundred students were selected through cluster random sampling. The sample included 400 students who were selected through multistage cluster random sampling. The research tools consisted of the General Self-Efficacy Scale (GSES) (37), Motivational Strategies for Learning Questionnaire (MSLQ) (41), Perceptions of Classroom Atmosphere Questionnaire (43), Intelligence Beliefs Questionnaire (45), and Achievement Goals Questionnaire (39). The inclusion criteria of the selected sample group were meeting the giftedness criteria according to based on the diagnosis of the Iranian Talent Education Organization, written consent of the sample and their parents, and homogeneity of the sample in terms of socio-economic status. The exclusion criterion include incomplete completion of questionnaires. The data were analyzed using structural equation modeling and path analysis.

\section{Results}

According to the results of the correlation matrix, achievement goals, self-efficacy, motivational beliefs, and perception of classroom atmosphere had a positive and significant relationship with selfregulated learning $(\mathrm{P}<0.01)$. Intelligence beliefs and motivational beliefs had a positive and significant relationship with achievement goals $(\mathrm{P}<0.01)$. To test the research hypotheses by structural equation modeling method, first the model fit indices were examined that all indices (RMSEA $=0.053, \mathrm{IFI}=0.927$, $\mathrm{CFI}=0.925, \mathrm{PNFI}=0.607, \mathrm{GFI}=0.927, \mathrm{X} 2 / \mathrm{df}=2.143$ ) confirmed the goodness of fit of the model. The results of the direct relationship of research variables in the final model (modified) showed that motivational beliefs, perception of classroom atmosphere, and self-efficacy had a significant and positive relationship with self-regulated learning. Besides, intelligence beliefs and motivational beliefs had a positive and 
significant relationship with achievement goals, and intelligence beliefs, motivational beliefs, and perception of classroom atmosphere had a positive and significant relationship with self-efficacy. Furthermore, the results of Bootstrapping test indicated that the indirect effect of motivational beliefs on self-regulated learning through achievement goals and self-efficacy was 0.2620 and 0.0726 , respectively, and the results were statistically significant. Additionally, the indirect effect of perception of classroom atmosphere on self-regulated learning through self-efficacy was 0.2166 , which was statistically significant.

\section{Conclusion}

This study examined a prediction model of selfregulated learning based on students' motivational beliefs, intelligence beliefs, and perception of classroom atmosphere while considering the mediating role of self-efficacy and achievement goals in students at gifted schools. The results showed that the variable of motivational beliefs had both direct and indirect significant effects on the selfregulated learning variable. This was in congruence with the previous research (17 and 28), who demonstrated that self-efficacy motivational belief had an indirect and positive impact on the academic achievement through mastery and performanceapproach goal orientations and learning strategies, however, they had an indirect and negative impact on academic achievement through avoidance performance.

Moreover, according to the results, the variables of intelligence beliefs affected self-regulated learning through self-efficacy and achievement goals. This is consistent with the findings of the study by Ganderson et al. (29), who revealed that besides their direct effect, intelligence beliefs had an indirect impact on the learning self-regulatory strategies of university students through achievement goals and academic self-efficacy. The subsequent results of the study demonstrated that perception of classroom atmosphere influences self-regulated learning through achievement goals. In congruence with the findings, Khani et al. (34) showed that the teacher's self-efficacy and students' perception of classroom atmosphere had a positive and significant relationship with the learning self-regulatory strategies of students at gifted schools. In addition, the findings of this study indicated that the achievement goals have a direct effect on self-regulated learning. The results of the studies $(10,11$, and 17) revealed that academic achievement had a positive relationship with the goal of mastery and strategic perception of classroom atmosphere and had a negative relationship with avoidance performance and strategy learning level. Therefore, students who consider themselves as selfefficient, employ more cognitive and metacognitive strategies and manifest more persistence in doing their homework.

One of the limitations of the present study is the lack of identification of students' intelligence by the researcher. Also, based on the results, other variables related to learning self-regulation (especially sociocultural factors) of gifted students should be examined in future studies to arrive at a more comprehensive understanding in this field.

\section{Ethical Considerations}

Compliance with ethical guidelines: The proposal of the present study was approved by the scientific committee of the Islamic Azad University (Central Tehran Branch), bearing letter No. 162311991 on 29.05.2019. The participants granted their full consent before entering this research.

Funding: This study was self-funded and it was carried out without receiving any financial funding from the university or any other organization.

Authors' contribution: The present article was extracted from the $\mathrm{Ph}$.D. dissertation of the first author under the supervision of the second author and with advisory consultation of the third author, registered by dissertation No. 10148004257151013981 62311991 and defended on 5.11.2020. The first author was the researcher and author of this article and the roles of other authors were research supervisor and advisor.

Conflict of interest: The authors declare no conflict of interest. Acknowledgments: The authors thank all those who contributed to this research. 


\section{ييش بينى خودتنظيمى ياد كيرى بر اساس باورهاى انتيزشى، باورهاى هوشى، و ادراكى دانش آموزان مدارس تيزهوشان

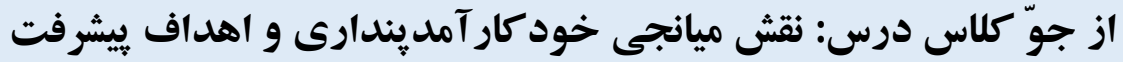

\section{مهسا جورابى عصر جديد'، منصوره شهريارى احمدى" "، مهديه صالحى"، مهناز استكى'}

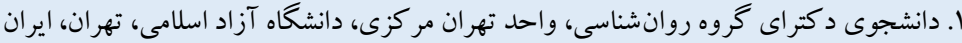

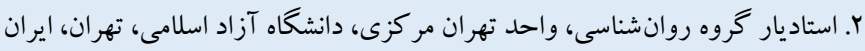

\begin{tabular}{|c|c|}
\hline جكيده & مشخصات مقاله \\
\hline زمينه و هدف: خودتنظيمى يادگيرى نقش بسيار مهمى در فرايندهاى آموزش و يادگيرى دانش آموزان دارد كه خود كار آمديندارى & كليدوازهها: \\
\hline تحصيلى و اهداف بيشرفت از عوامل مؤثر در توسعه اين توانايى هستند. بدين ترتيب هدف بثزوهش حاضر، بررسى مدل بيشيبنى خود تنظيمى & خودتنيمى يادگيرى، \\
\hline ياد كيرى بر اساس باورهاى انخيزشى، باورهاى هوشى، و ادراكى از جوّ كلاس با در نظر كرفنن نقش ميانجى خود كار آمديندارى و اهداف & 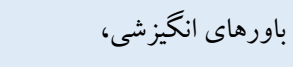 \\
\hline يُيشرفت در دانش آموزان مدارس تيزهوشان بود. & 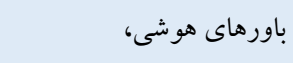 \\
\hline روش: مطالعه حاضر از نظر هدف، كاربردى و از نظر روش گردآورى دادهها همبستخى بود. جامعه آمارى يُوهش حاضر تمامى دانش- & \\
\hline 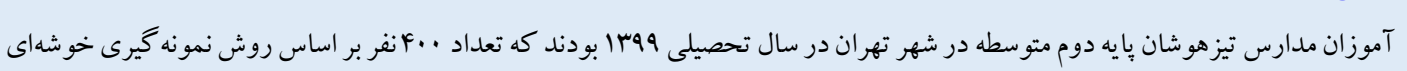 & 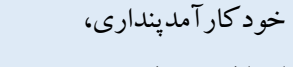 \\
\hline تصادفى انتخاب شدند. ابزار يُزوهش شامل برسشنامه خود كار آمديندارى عمومى (شرر و همكاران، 19AY)، مقياس خود تنظيمى يادكيرى و & اهداف بيشرفت \\
\hline 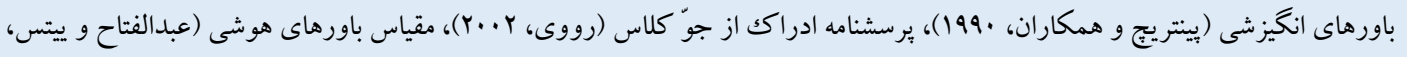 & \\
\hline 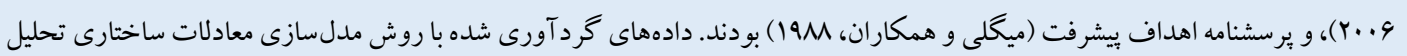 & \\
\hline شدند. & \\
\hline يافته ها: بر اساس نتايج، بين متغيرهاى اهداف يِيشفت، خود كار آمديندارى، باورهاى هوشى، باورهاى انخيزشى، و ادراكى از جوّ كلاس با & \\
\hline 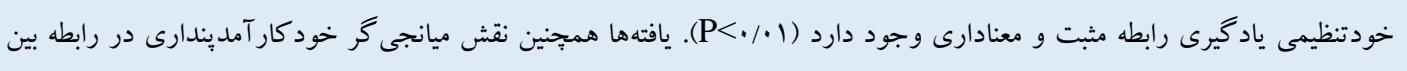 & \\
\hline باورهاى انخيزشى و ادراكى از جوّ كلاس با خودتنظيمى ياد كيرى و نقش ميانجى گر اهداف بيشرفت در رابطه بين باورهاى انكيزشى با & \\
\hline خودتنظيمى ياد خيرى را مورد تأييد قرار داد. & 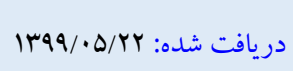 \\
\hline نتيجه كيرى: نتايج نشان داد شاخص هاى برازش مدل يزووهش در وضعيت مطلوبى قرار دارد. همجنين متغير باورهاى انخيزشى بر متغير & 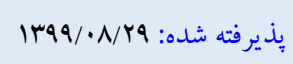 \\
\hline خودتنظيمى ياد گيرى، هم اثر مستقيم و هم اثر غيرمستقيم معنادارى دارد. & 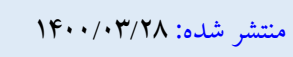 \\
\hline
\end{tabular}

* نويسنده مسئول: منصوره شهريارى احمدى، استاديار گروه روانشناسى، واحد تهران مركزى، دانشگاه آزاد اسلامى، تهران، ايران.

Serdeh58@yahoo.in :رايانامه

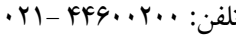


و ســازمـاندهى ") و راهبردهـاى فراشــناختى (طرحريزى "جا، نظارت بر

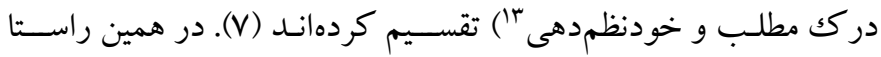

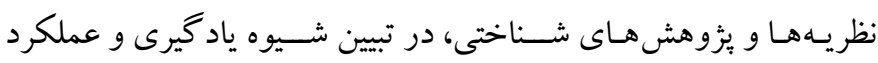

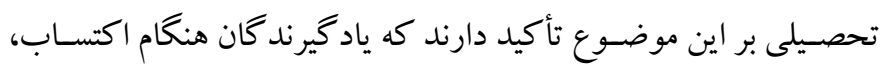

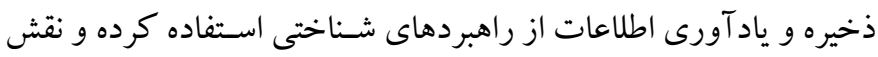

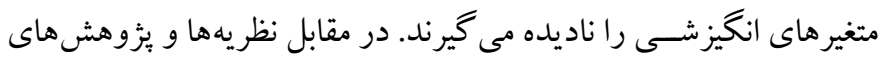

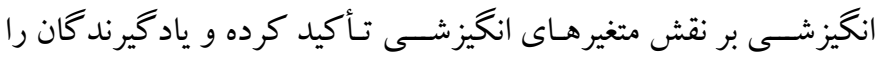

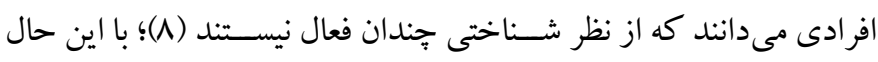

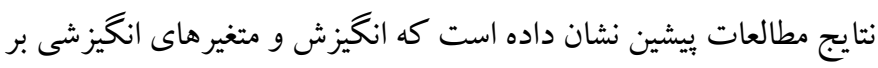

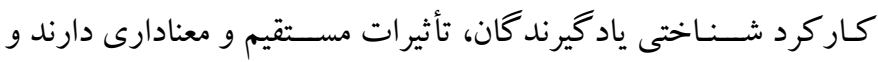

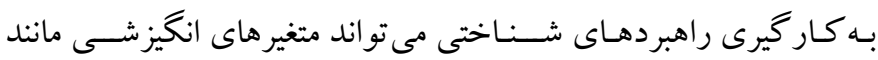

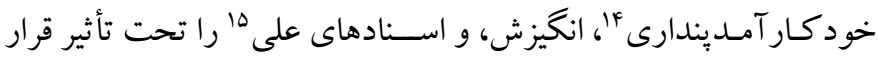

كـالـان و كلرى معتقـدند كه هر جهه فراخيران از اين راهبردها بيشـــر

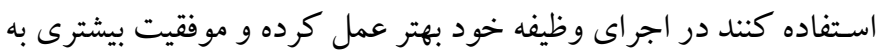
دسـت مى آورند ( • (). بررسى هاى اسـوالاندر و توب در اين زمينه نشـان

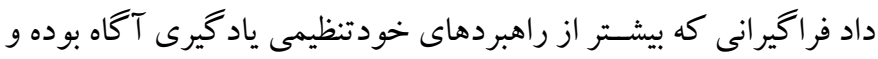

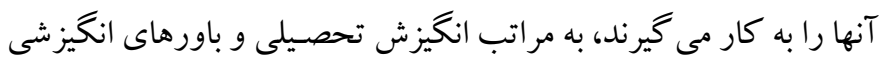

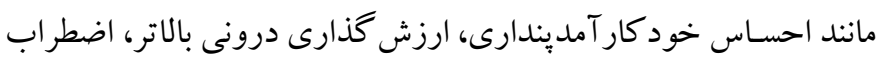

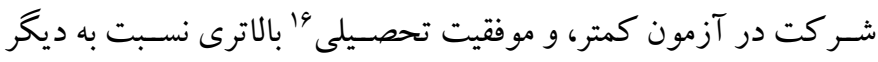

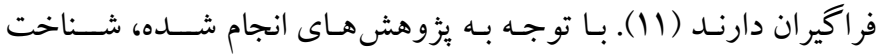
متغيرهـاى مؤثر بر خودتنظيمى يـادگيرى، بـهـ ييشبينى بهتر اين متغير مى انجامد و سبب بهبود فر ايند ياد گيرى مى شود (r) (I).

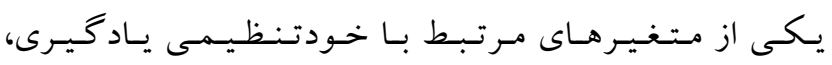

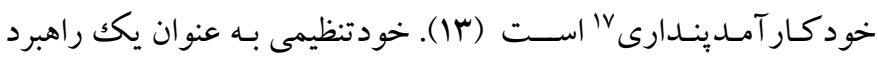

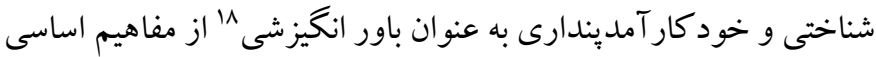

11. Organization

15. Contrivance

16. Self-regulation

14. Self-efficacy

15. Causal attribution

16. Academic success

17. Self-efficacy

18. Motivational belief
مقدمه

ياد گيرى يكى از موضــوعات مهم و مورد علاقه روانشــناســان و علماى

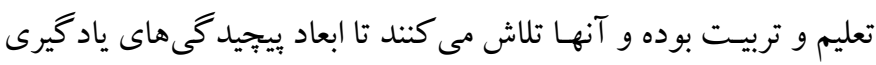

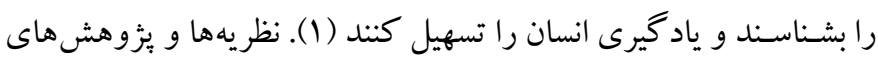

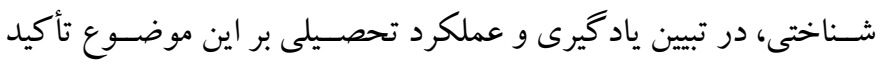

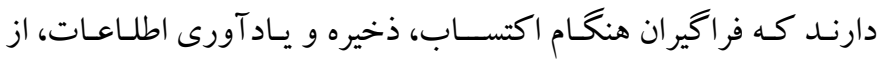
راهبردهاى شـناختى ' استفاده كرده و نقش متغيرهاى انخيزشى رده را ناديده

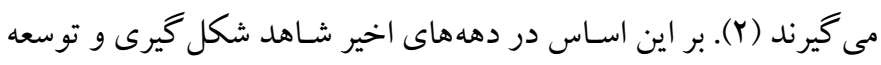

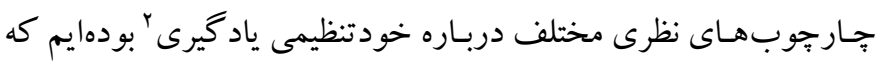

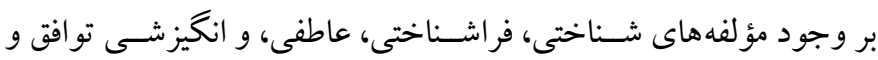
اشتراكك نظر دارند (r).

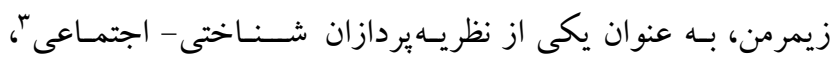

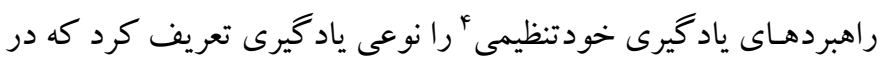

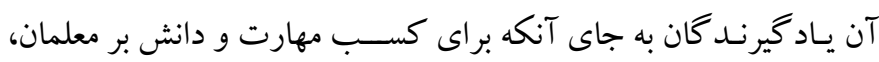

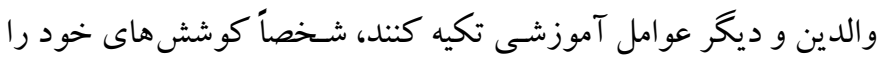

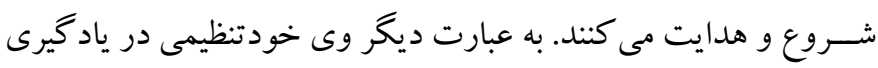

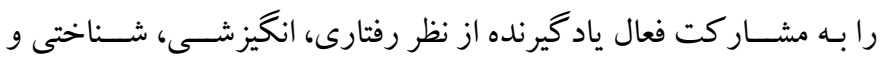

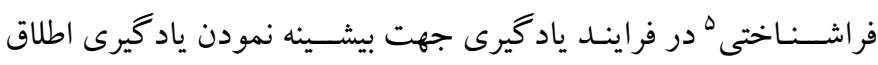

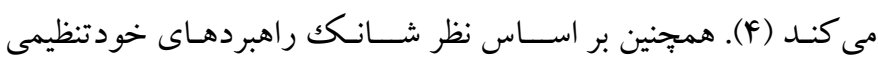

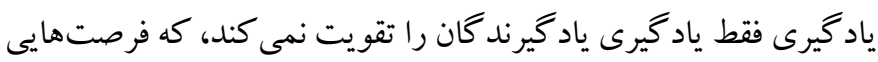
را براى آنـان فراهم مى آورد تـا بـهـ طور فعـال فراينـدهـايى مـانــــ تنظيم

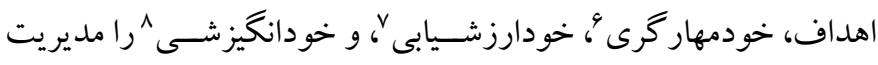

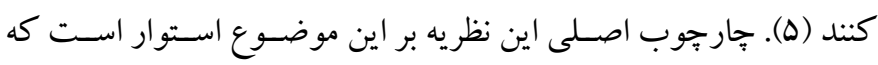

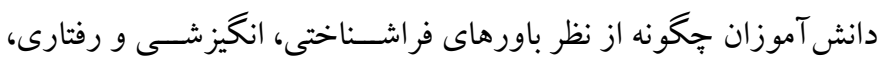

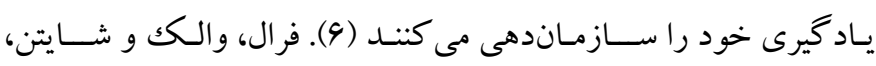

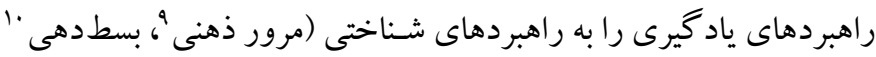

1. Cognitive strategies

2. Self-regulation learning

3. Cognitive-social theory

4. Self-regulatory learning strategies

5. Cognitive and metacognitive

6. Self-control

7. Self-assessment

8. Self-motivation

9. Mental review

10. Expansion 
اشـاره دارند؛ جهه اين زمينه ها آكادميكك باشــد (مانند تكاليف در كلاس

درس يا آمادهسازى آزمون) جهه نباشد (مانند ورزش و تنظيمات كار).

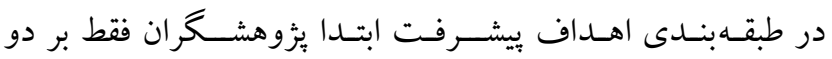
جهـت گيرى تبحرى و عملكردى هـأكيـد مى كردنـد، ولى نظريسهــاى

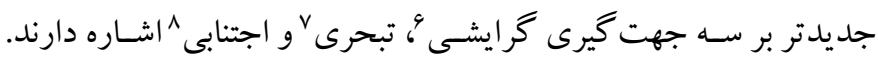
اهــاف ييشــرفت در تكليف، به غلبه بر كشــاكشها يا افزايش ســـح كفايت و بهبود توانايى افراد اشـاره دارند؛ در حالى كه اهداف اجتناب از تبحر افراد بر روى اجتناب از بدفهمى، تسـلط نيافتن بر تكليف و اسـتفاده

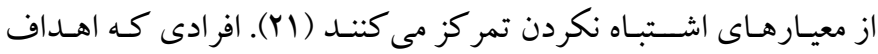
عملكرد - اجتنابى دارند، بر نشان دادن شايستگى و قضاوت هاى نامطلوب تمر كز مى كنــد (YY). نتايج مطالعات نشــان دادهاند كه اهداف تبحرى با خود كار آمديندارى تحصسيلى بالا، اسـتفاده از راهبردهاى شـناختى عميق، مقابله كار آمد با مشكلات و كامنايافتكى هاى تحصيلى، بيشرفت تحصيلى بـالـا، و هيجـانـات و نيمرخ انكِيزشـى مثبـت، رابطه مثبتى دارد. همجنين اهداف اجتنابى، رابطه منفى با خود كار آمديندارى و يايدارى در تكاليف، و رابطه مثبت با اسـتفاده از راهبردهاى سـطحى ياد گيرى، اضـطر اب و به طور كلى هيجـانات منفى دارد (سM). يافته هاى ئزوهش اشــنايدر و يركل نشـــان داد كه ييشـــرفت تحصــيلى با هدف تســلط با راهبردهاى (YF)

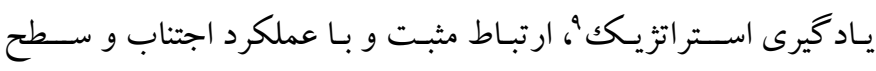
يـاد گيرى اسـتر اتزيـك '، ارتبـاط منفى دارد (YF). در مطـالعسهاى ديخر مشــخص شــد كه فراكير ان داراى اهداف تبحرى به ميزان بالايى درگير

مطالعه شده و تكاليف مدرسه را معنادار مىدانند (Yه). در دو دهه اخير راهبردهاى يادگيرى و باورهاى انخيزشى " به عنوان متغيرهاى نظام آموزشى ظهور يافتند (Y9). باور افراد نسبت به دست يافتن به اهداف مطلوب شـان موجب رضـايتمندى آنها از زندگى مى شود. در روانشـناسـى فرايندهاى منجر به تحقق اهداف، انخيزه ناميده مى شــوند. انخيزه، عبارت از عواملى در درون ار كانيسم فرد است كه رفتار وى را به سوى هدف مشخصى سوق داده و حفظ مى كند (YV). باورهاى انخيزشى

\section{Master}

8. Avoidance

9. Strategic learning strategies

10. Strategic learning level

11. Motivational beliefs
نظريه بندورا' به شـمار مىروند (I) (I). بر اسـاس نظريه بندورا رفتار آدمى يكك رفتار خودتنظيم اسـت (I) (I). از جمله موضسوعاتى كه انسان از تجربه مســتقيم يـا غيرمســتقيم مى آموزد، معيـارهـاى عملكرد بوده كـه يس از آموزش، اين معيارها يايهاى براى ارزشـيابى شـخصى فرد مىشـوند. اكر عملكرد شـخص در يكك موقعيت معين با معيارهاى او هماهنگك يا از آن بـالاتر باشــد، آن را مثبت ارزيابى مى كند، اما اخر بإيينتر از معيارهاى او باشـــ، آن را منفى ارزشـيابى مى كند (ها ). خود كار آمديندارى به عنوان

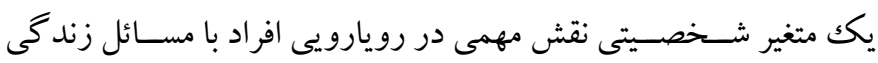
دارد. برحسبـ نظر بندورا وقتى فرد باور داشته باشد كه تو انايى بيشرفت و كسـب موفقيت در زمينه تحصـيل را دارا اسـت به خود كار آمديندارى تحصيلى دست يافته است و باورهاى خود كار آمدى شخصى، دقيقاً تفسير

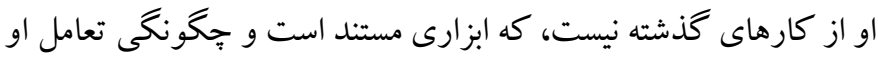
را بـا محيط و افراد ديخر ممكن مىســازد. خود كـار آمـديندارى ادراك

شده، قضاوت فرد درباره قابليت هاى خويشتن است (IF). مطابق با متون روانشـناسى، دلايل و اهداف دانش آموزان براى انجام فعـاليتهاى تحصــيلى از اهميت زيادى برخوردار اســت. در اين ميان، نظريه جهت كيرى هدف ` يا اهداف بيشــرفت بّا روى آوردى شــاختى اجتمـاعى، از جملـه نظريـهـهـاى بســيار ســـودمندى اســت كه به مفهوم هدف گر ايى ب به عنوان اسـاسـى ترين مفهوم انخيزشـى توجه كرده اسـت (IV) (جهت كيرى هدف، تبين كننده انكيزهاى اســت كه بر اســاس آن رسيدن به هدف تعقيب مىشـود و بر قصد و نيت افر اد براى بيشرفت در تكاليف (جرايى تلاش) تأكيد دارد (N). اهداف ييشرفت در واقع معرف يكك ســــــتم معنايى جامع از موقعيت ها يا بافتهايى اســت كه داراى بيامدهاى شناختى، عاطفى و رفتارى هستند و فراكيران براى تفسير اعمال خود از آنها اسـتفاده مى كنند (19). در نظريه اهداف بيشـــفت، فرض بر اين است كه اهداف فراكيران بيشبينى كننده مهمى براى فرايندها و نتايج

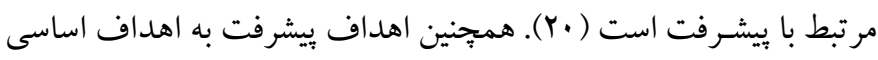
يك شــخص هنگًامى كه در زمينه هاى مختلف بيشــرفت در گير اســت،

1. Bandura

2. Goal orientation theory

3. Progress goals

4. Goal-oriented

5. Functional oreentation

6. Approach 
نظريههاى هوش بيانكر اين موضسوع هسـتند كه آيا ادراك دانش آموزان

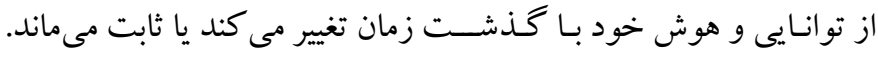

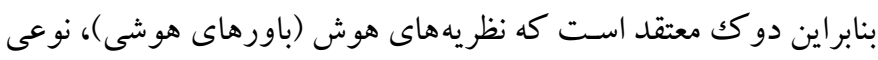

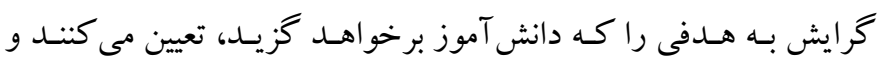

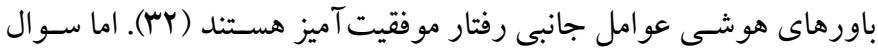

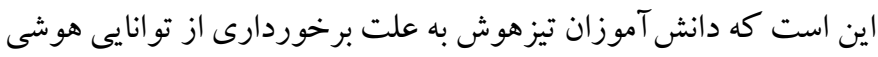

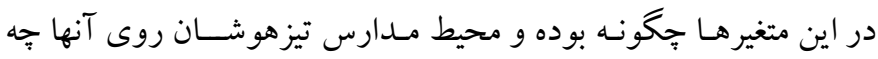
تأثيرى دارد.

علـاوه بر ويز گیىهـاى فردى دانش آموز، آموزش ويرورش نيز نهادى

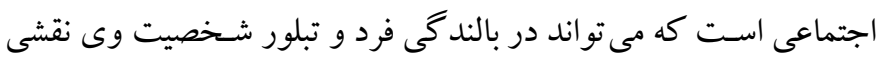

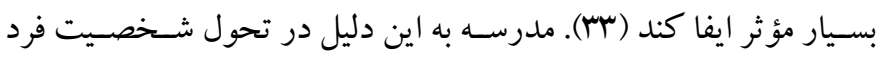

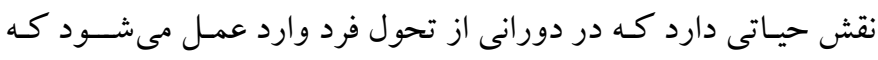

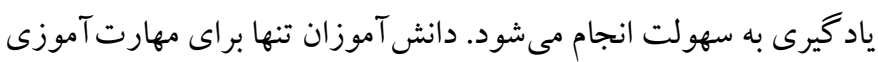

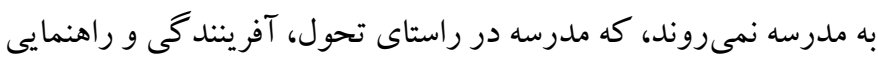

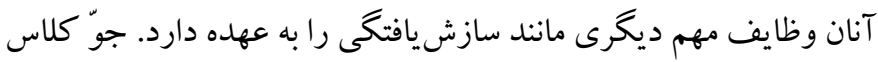

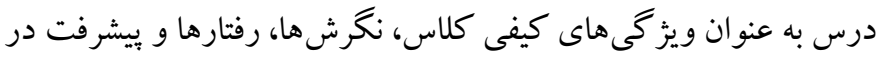

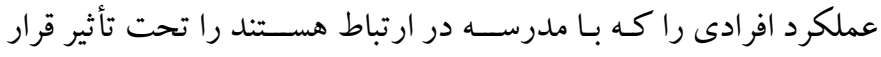
مى مهد و حاصل روابط و كنشهاى ميان گروههاى درون مدرسه است. توجه به جوّ كلاس و سـاير نظامهاى آموزشى اهميتى مضاعف دوان دارد، زيرا

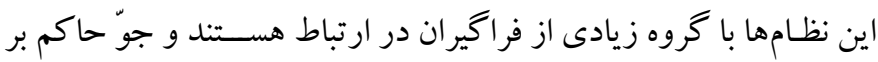

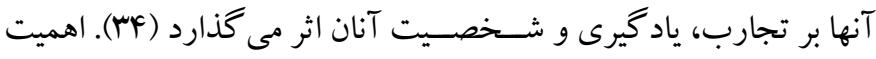

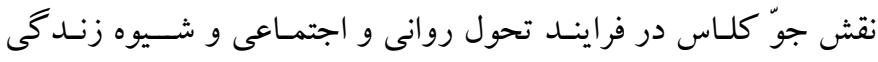

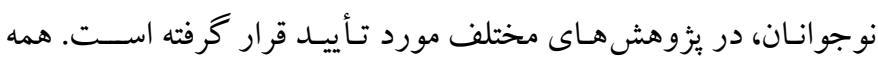

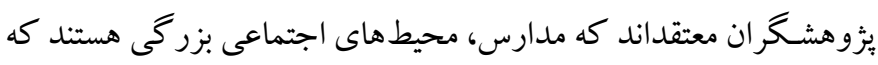

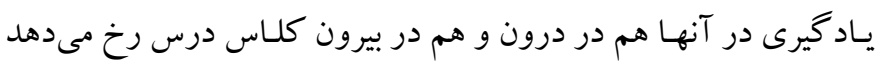

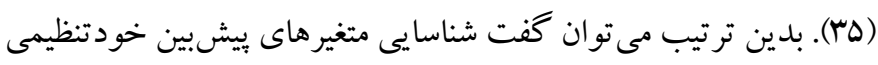

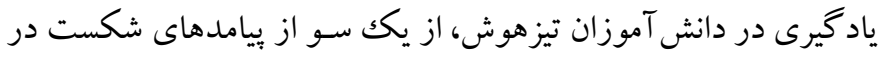

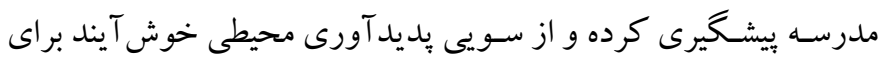

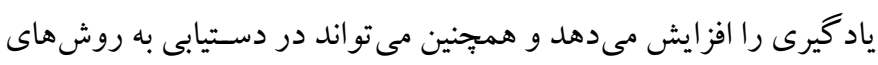

5. Dweck 's social cognitive approach

6. Intelligence beliefs

7. Incremental intelligence belief

8. Innate intelligence belief
بر اسـاس نظرات يينتريج و دى گروت ' به سه مؤلفه انتظارى'، ارزشى"، و

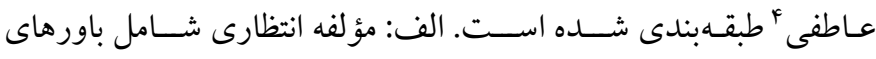

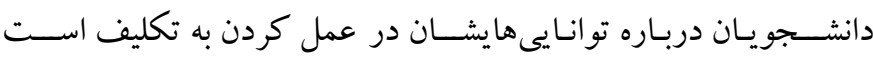

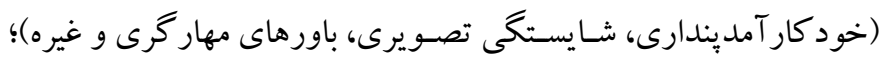
ب: مؤلفه ارزشـى شــــل اهداف دانش آموزان و باورهاى شـــان درباره

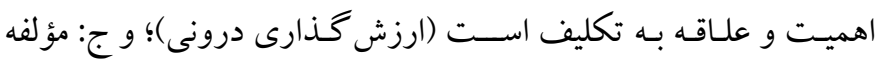
عاطفى شامل واكنش هاى هيجانى به تكليف است. بر اساس يزو هش هاى

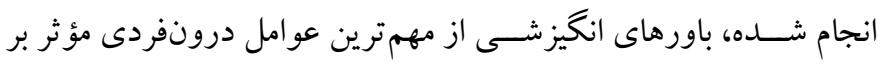

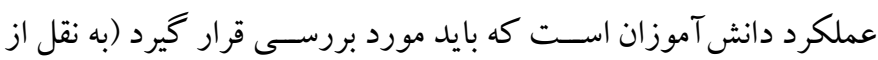

روى آورد ديخرى كه در تعيين رابطه ميان عوامل شناختى و انگيزشى

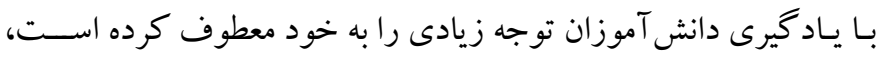

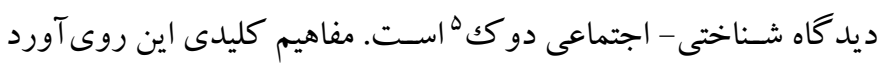

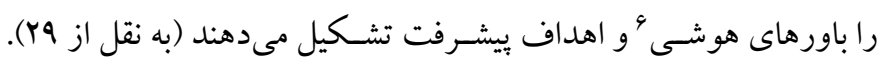

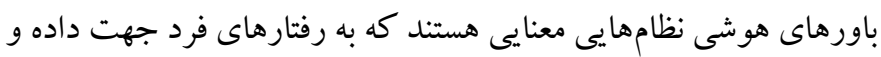

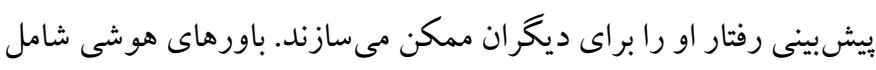

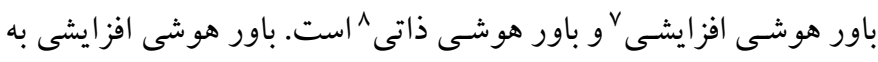

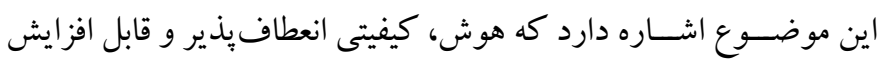

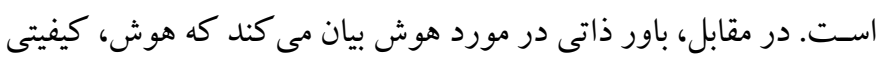

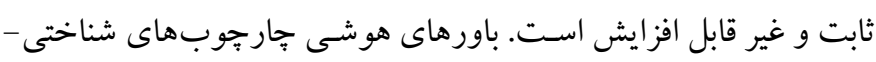

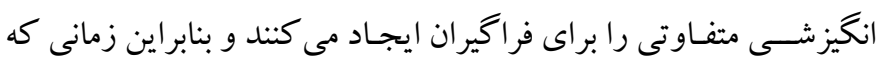

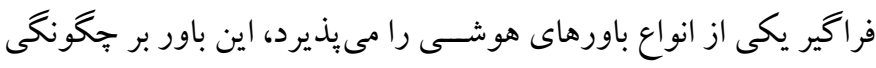

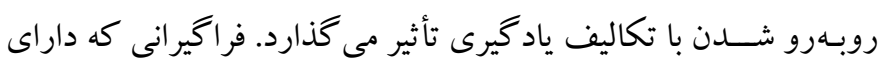

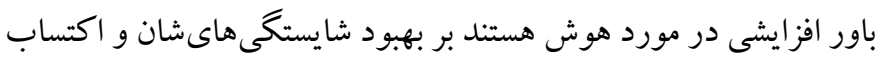

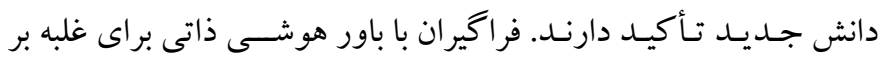

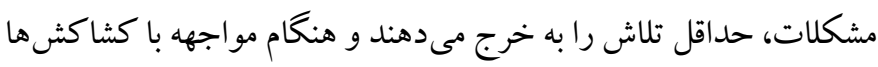

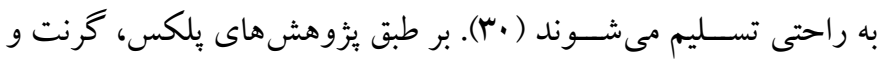

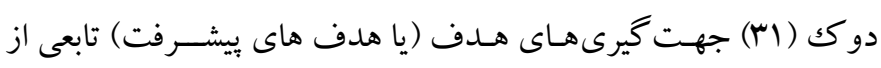

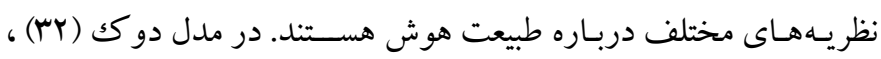

1. Pintrich \& De Groot

2. Expected component

3 . Value component

4. Emotional component 


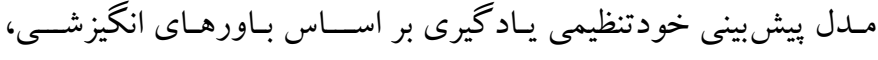

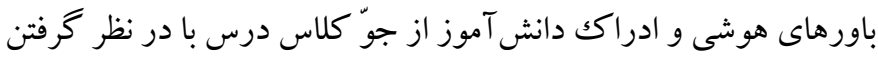

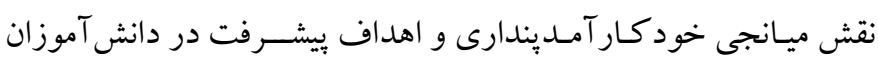
مدارس تيزهوشان از برازش خوبى برخوردار است يا خير.
منـاسـبـ و تكيـه بر اولويـتهاى كاربردى كمكك كند. با توجه به اينكه تر كيب متغيرهاى يزوهش حاضر در گروه دانش آموزان شاغل به تحصيل

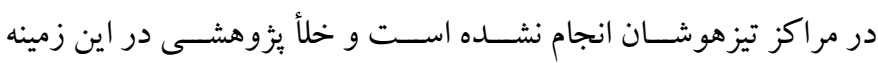

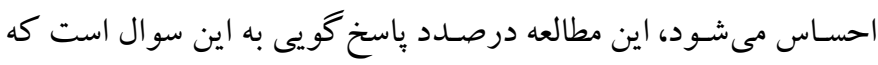

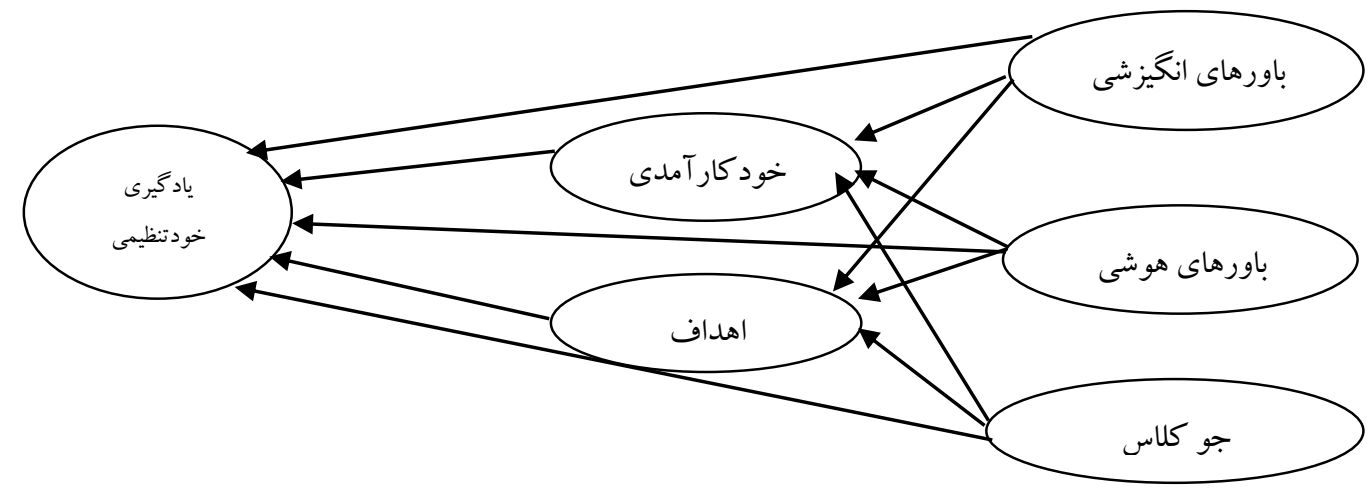

شكل 1. مدل مفهومى يخوهش

بر آورد شــــه حداقل · ل آزمودنى كافى اســت؛ به شــــ اين كه اندازه

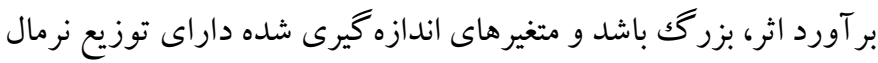
باشـــ (4). بنابر اين حداقل نمونه يزووهش حاضـر با در نظر كرفتن تعداد

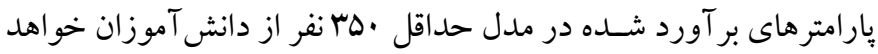

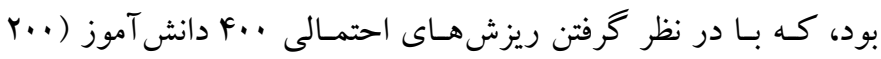

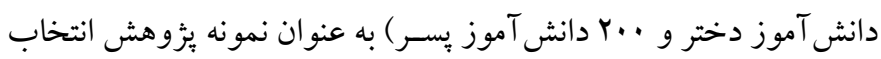

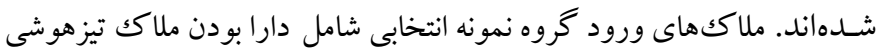
بر اســاس تشـخيص ســازمان آموزشويرورش اسـتعدادهاى درخشــان ايران،

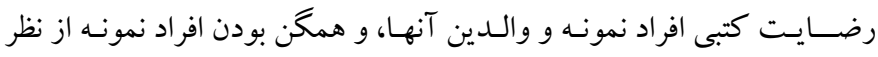

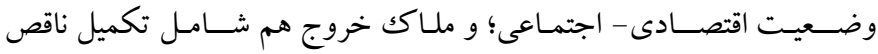

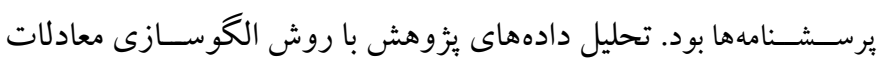
ساختارى و تحليل مسير، انجام شد.

$$
\text { ب) بابزار }
$$

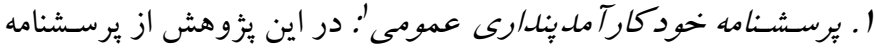

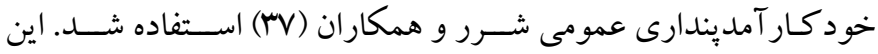

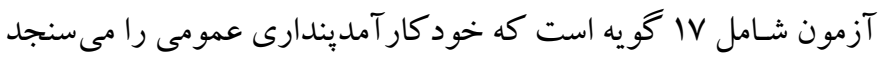

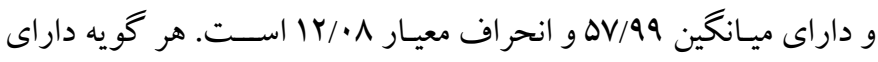

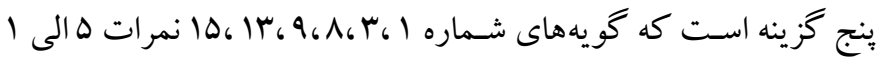

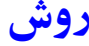
الف) طرح يزوهش و شـــ كت كنند كان: روش يزوهش حاضـر از نظر

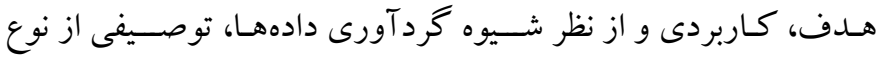

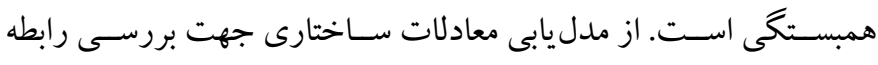

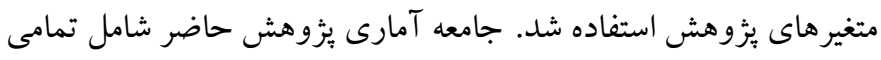
دانش آموزان مدارس تيزهوشـان بايه دوم متوسطه (دختر و بسر ) در شهر تهران در سـال تحصـيلى 99-هوس| بودند. للازم به ذكر اسـت كه ملاكك تيزهوش بودن در اين مطالعه، بر اساس سنجش انجام شده توسط سازمان

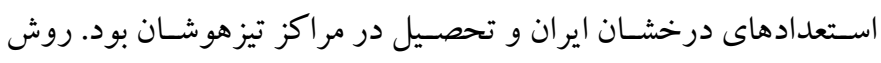

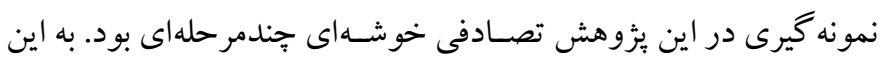
صسورت كه از ميان مدارس بايه دوم متوسطهة تيزهوشـان در شـهر تهران ابتدا مناطق آموزشى عا و Y و از هر منطقه، دو مدرسه به تصادف انتخاب شدند. در مرحله بعد از هر مدرسه جهار كلاس به تصادف انتخاب شدند.

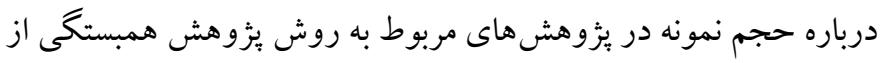

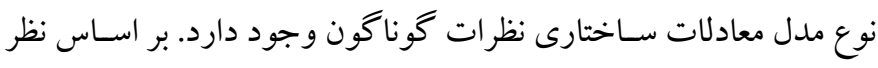

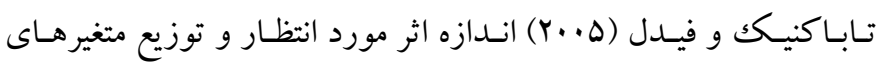

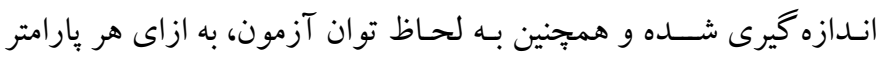


جهت گيرى عملكردى - اجتنابى rA/•، و كل آزمون به/•. للزم به ذكر

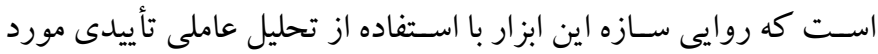

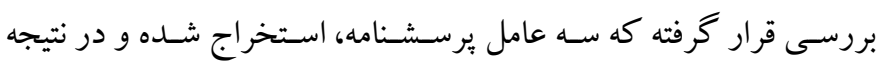
روايى عاملى آن تأييد شده است.

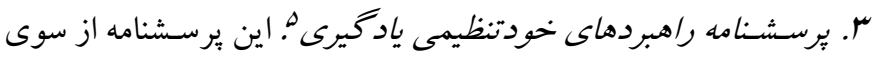

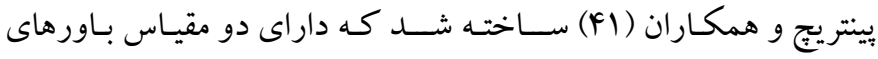

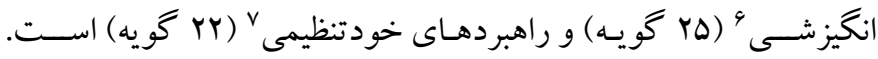

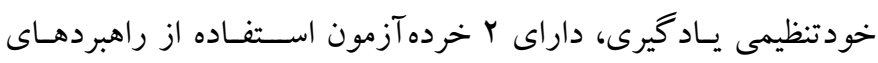

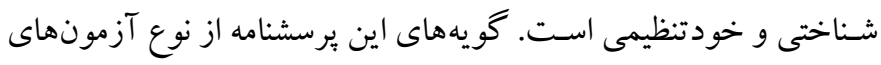

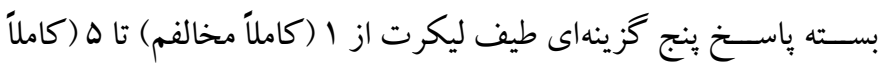

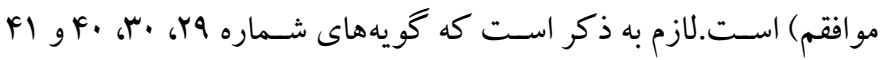

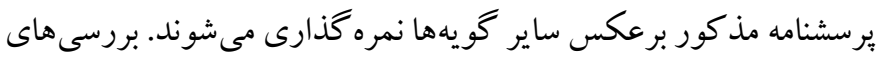

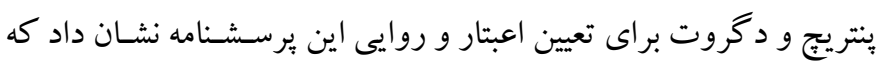

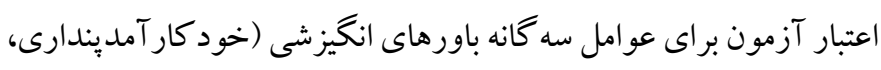

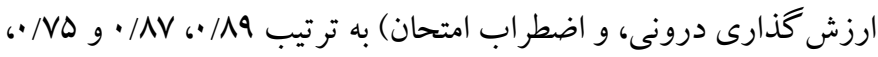
و براى مقياس راهبردهاى خودتنطيمى ياد گيرى (راهبردهاى شـــناختى و

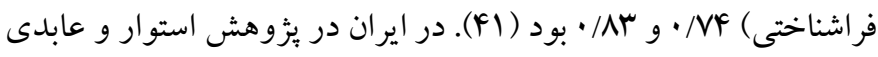

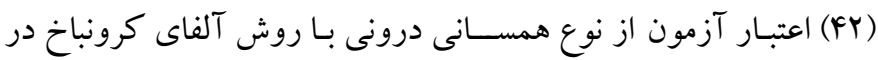

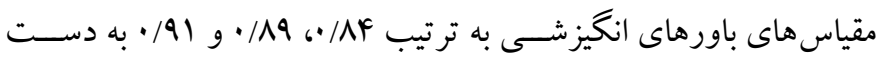

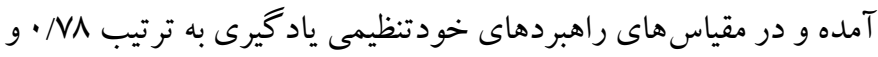

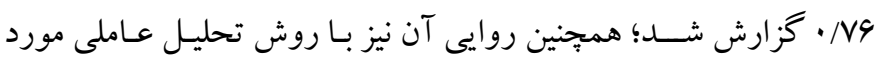
تأييد قرار كر فته است.

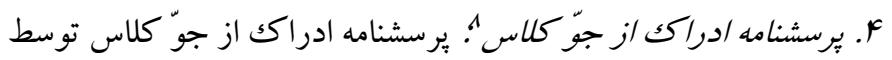

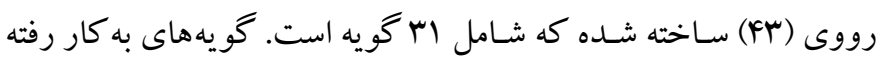
در اين يرسـشــامه، برداشـت فرد را از كلاس و فعاليتهاى كلاسـى وى

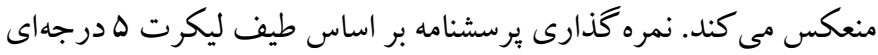

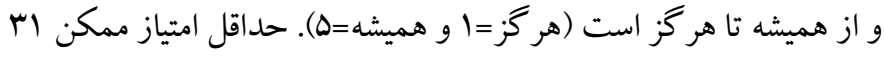

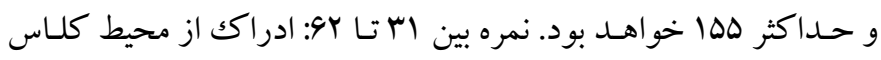
نامطلوب است. نمره بين بو تا سه: ادراك از محيط كلاس متوسط است.

5. Motivational Strategies for Learning Questionnaire (MSLQ) 6. Motivational beliefs

7. Self-regulatory strategies

8. Rovy's Perceptions of Classroom Atmosphere Questionnaire
مى گيرند و بقيه گويهها بر حسب نمر اتى از ا تا هـ نمره گذارى مى شوند.

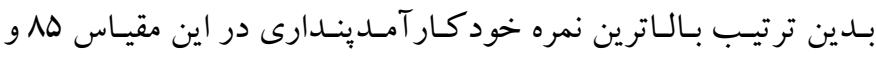

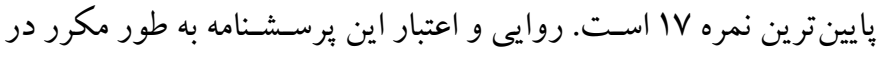

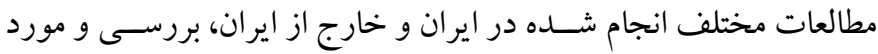

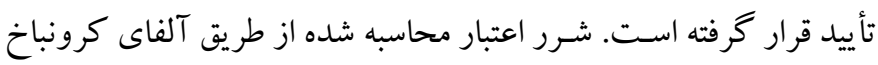

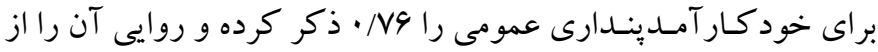

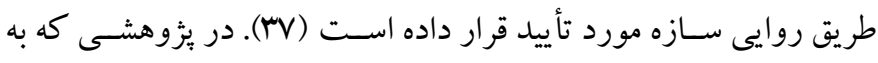

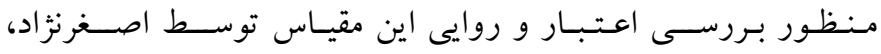
احمدى دهقطبالدينى، فرزاد و خدايناهى (N) انجام شــده اسـت، جهت بررسى روايى از روش تحليل عاملى اكتشافى و تأييدى استفاده كردهاند

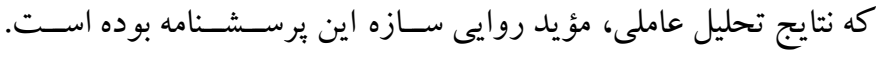

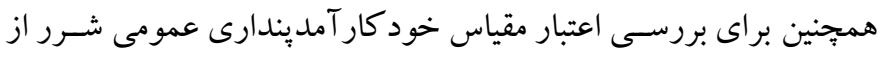

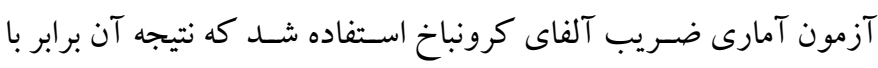

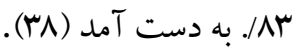

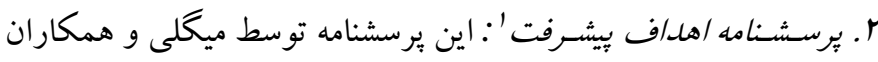

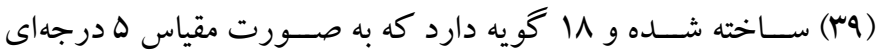

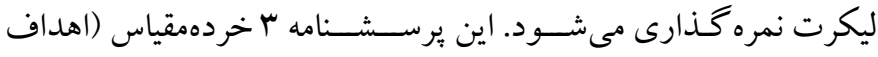

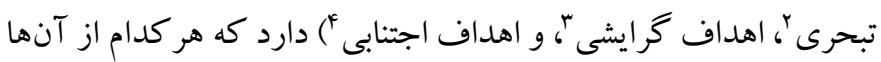

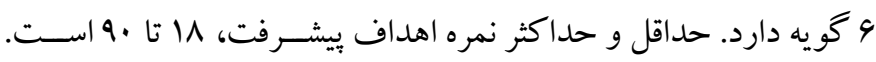

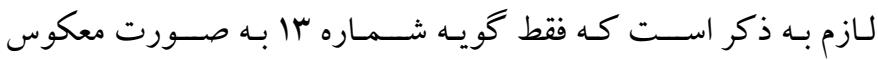

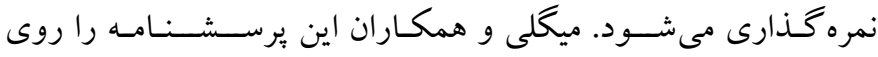

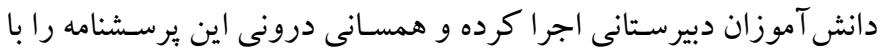

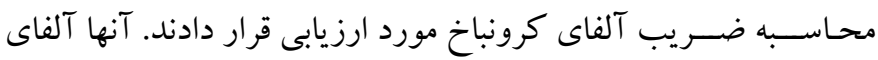

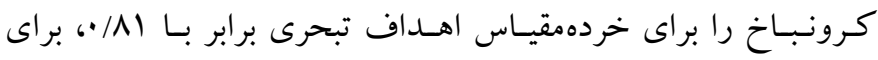

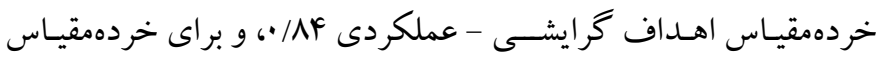

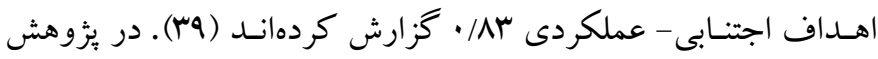
شـيرازى، مرضسيه و نظرى (•F) ضـرايب آلفاى كرونباخ به دسـت آمدره

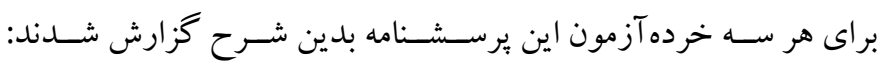

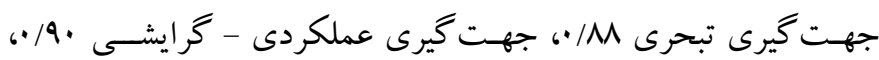

1. Achievement goals questionnaire

2. Skills goals

3. Trend goals

4. Avoidance goals 
برازش قابل قبولى با دادهها داشـته اسـت. اين بزوهشـكران با توجه به شـاخص هاى روانسـنجى محاسـبه شـده نتيجه گيرى كردند كه مقياس مورد نظر براى ارزيـابى بـاورهـاى هوشــى مىتوانــ مورد اســتفاده يثزوهشخران قرار بكيرد (F4).

ج) روش اجرا: جهت اجر اى اين بثزوهش بعد از هماهنكى با آموزش و يرورش شــهر تهران و كســب مجوز نمونه گيرى و هماهنكى با مديران،

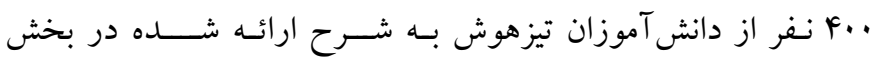
روششـاسى، انتخاب شده و آزمون گر در مدارس حضور يافت. بِ از اتمام سـاعت درسى، همه دانش آموزان داراى ملاككهاى ورود در كلاس ماندند و يزوهشخر منطق باسخ گويى به ابزارها را به دانش آموزان توضيح داد. جهت رعايت اصول اخلاقى از دانش آموزان درج نام خواسته نمىشد و در صسورت عدم تمايل به تكميل برسـشـنامه، اين امكان فراهم مىشـد. يرسـشـنامه ها به صـورت انفر ادى و توسط خود دانش آموزان تكميل شد. براى تحليل دادهها از نرمافزارهاى SPSS و 23 و Amos اســفاده شــــه است. سطح معنادارى نيز هـ/ • در نظر كرفته شده است.

بافتها در جدول الشـاخص هاى توصيفى متغيرها شامل ميانخين، انحر اف معيار،

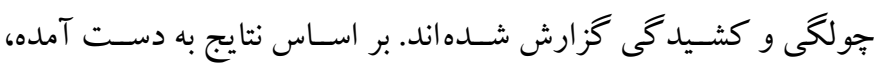

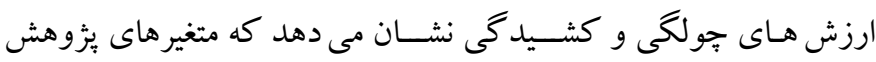
توزيع نرمال دارند.
نمره بـالاتر از سه: ادراكك از محيط كلاس مطلوب اســت. براى بررسـى اعتبار اين مقياس از آزمون آمارى ضريب آلفاى كرونباخ استفاده شد كه نتيجه آن برابر با م// • به دست آمد و همجنين شكل هاى مختلف روايى اين برسسشـنامه مورد تأييد قرار كرفت (FT). در بزظوهش جوادى علمى و اســزاده روايى محتو ايى برسـشـنامه توسط استادان دانشخاه و متخصصان تأييد شـده و همجينين اعتبار آن از طريق آلفاى كرونباخ ·V/ • ذكر شـده

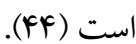

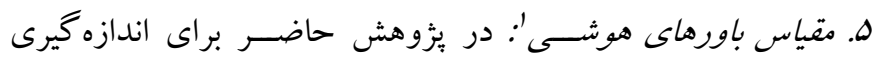

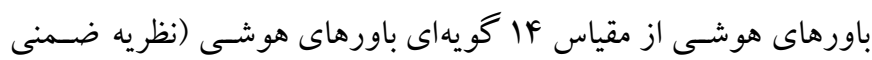
هوش) عبدالفتاح و يتس (FD) اسـتفاده شـده اسـت. در اين يرسـشـنامه،

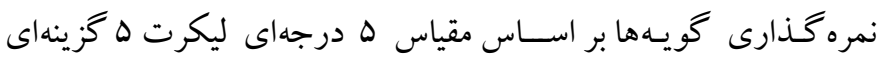

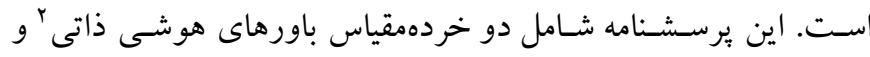
باورهاى هوشى افزايشىى است. ضرايب آلفاى كرونباخ خزارش شده توسط عبدالفتاح و ييتس (4. . ب) براى خردهمقياس نظريه افزايشى هوش

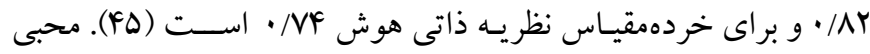
نورالدينوند و همكاران (\&4) براى برآورد روايى ملاكى اين مقياس از مقياس نظريه ضــمنى هوش "ُدوبيرات و مارينه اســتفاده كردند كه ضـرايب همبسـتِى بين خردهمقياسهاى نظريه افزايشسى و نظريه ذاتى هوش در دو مقياس محاسـبه شـد و در سطح | + / • معنادار بود. همجنين براى محاسـبه روايى سـازه مقياس از تحليل عامل اكتشـافى و تأييدى اسـتفاده كردند كه نتايج نشـان داد سـاختار مقياس نظريه ضسمنى هوش،

جدول ا: يافته هاى توصيفى متغيرهاى بزوهش

\begin{tabular}{|c|c|c|c|c|c|c|}
\hline كشيد & جولكى & بيشينه & كمينه & انحر اف معيار & ميانگين & متغير هاى بثوهش \\
\hline $1 / 41$ & $-1 / 19$ & va & $\Delta r$ & $F / V V$ & $9 \mathrm{~V} / \cdot \mathrm{A}$ & خودتنظيمى يادگيرى \\
\hline 1/NQ & - & 99 & $\Delta$. & $V / r I$ & $V G / N I$ & اهداف ييشرفت \\
\hline$r / Y F$ & $\cdot$ / rAF & $\wedge 9$ & $\mathrm{kr}$ & $9 / 1 F$ & $\Delta \Delta / q$. & خود كار آمديندارى \\
\hline I/FY & $-\cdot / 4 \cdot \Delta$ & rA & r & $r / F$. & FI/GF & باورهاى هوشى \\
\hline.$- / \cdot 9 r$ & -.1911 & 4. & ro & $9 / 11$ & $\Delta r / I T$ & باورهاى انگيزشى \\
\hline$r / q V$ & $-1 / \wedge \Delta$ & $\checkmark$ & r & $1 / r 9$ & $9 / 1$. & ادراك از جوّ كلاس \\
\hline
\end{tabular}

4. Implicit theories of intelligence scale (IT IS)

5. Dupeyrat \& Marine
1. Intelligence Beliefs Questionnaire

2. Inherent intelligence belifs

3. Incremental intelligence belifs 
جدول Y اطلاعات مربوط به همبستكى بيرسون بين متغيرهاى بزّوهش را نشان مىدهد.

جدول r: ماتريس همبستغى بين متغير هاى يزوهش

\begin{tabular}{|c|c|c|c|c|c|c|}
\hline 7 & 0 & $\varepsilon$ & $r$ & r & 1 & متغير هاى ثخوهش \\
\hline & & & & & 1 & 1.خودتنظيمى ياد گيرى \\
\hline & & & & 1 & $\cdot / / 4 . * *$ & r.اهداف ييشرفت \\
\hline & & & 1 & $\cdot / \cdot V r$ & $\cdot / r \mu \Lambda^{* *}$ & r.خو دكار آمديندارى \\
\hline & & 1 & $\cdot|r 9| * *$ & $\cdot / r \cdot \uparrow * *$ & $\cdot / \cdot r \Lambda$ & F.باور هاى هوشى \\
\hline & 1 & $\% r$ & $. / 94 . * *$ & $\cdot / \Delta r q * *$ & $\cdot / r r \Delta * *$ & هـباورهاى انخيزشى \\
\hline 1 & .1 .90 & $\cdot / \Gamma \wedge \mid * *$ & $\cdot / \Gamma \cdot \wedge * *$ &.$/ \cdot \Delta \Delta$ & $\cdot / Y I 1 * *$ & و.ادراكك از جوّ كلاس \\
\hline
\end{tabular}

$* * \mathrm{P}<\cdot / \cdot 1$

جهت بررسـى علم وجود دادههاى يرت جندمتغيرى، شــاخص فاصسله مـاهالانوبيس '، مورد بررسـى قرار كرفت كه ســوح معنادارى كمتر از ه• • • حاكى از دور افتاده بودن دادههاى برت مورد نظر اسـت. براسـاس اين شـاخص، داده يرت شـناسـايى نشـد. همجنين بررسى ييشفرض هاى آمارى نشـان داد كه روش مدليابى معادلات سـاختارى، روش مناسـبى براى ارزيابى برازش مدل است و جهت بر آورد بارامتر ها از روش بيشينه درستنمايى + استفاده شده است. شاخص Rيز ان واريانس تبيين شده متغيرهاى نهفته درونزا را نشان

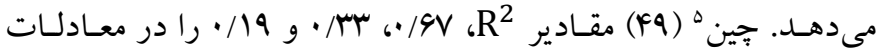
سـاختارى به ترتيب قوى، متوسـط و ضسعيف توصسيف مى كند. ضـريب تعيين متغير خودتنظيمى ياد گيرى در الخوى ساختارى اصلاح شده ·AY/. اسـت كه نشـان مى دهد متغيرهاى برونزاو ميانجى يعنى اهداف بيشرفت، خود كار آمديندارى، باورهاى هوشى، باورهاى انكيزشى، و ادراكك از جوّ كلاس مى توانند Y د درصــ از تغييرات خود تنظيمى ياد گيرى را ييشبينى كنند كه اين ميز ان در حد متوســ به بالا اسـت. جدول ب شــاخصهاى برازش الكوى ييشنهادى، اصلاح شده، و نهايى را نشان مىدهد كه حاكى از آن است الكوى نهايى بثوهش از برازش خوبى برخوردار است.

4. Maximum likelihood (ML)

5. Chin

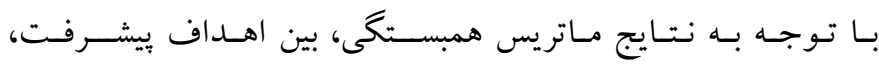

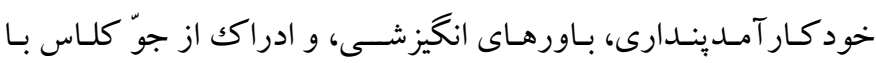
خود تنظيمى يـاد گيرى رابطـه مثبـت و معنـادارى وجود دارد ( ( • • (P). بين باورهاى هوشى و باورهاى انگگشى با اهداف يِيشرفت رابطه مثبت و

$$
\text { معنادارى وجود دارد (1) (P<). }
$$

در يزوهش حـاضــر جهت بررســى برازش رابطه از روش مدل يابى

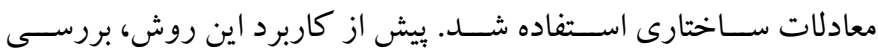
ييشفرض هاى اين روش آمارى ضرورى است. بنابر بيشنهاد كلاين (FV) مفروضــهــاى بهنجـارى تـككتغيرى بـه كمكك بر آورد مقادير كجى و كشيدكى آزمون و تأييد شدند. با توجه به اينكه دامنه كجى و كشيدگى متغيرها در بازه Y \ـ قرار داشــت، نرمال بودن تكك متغيرى مورد تأييد قرار كرفت (جـدول ()). جهت بررسـى نرمال بودن جندمتغيرى از ضــريب كشـيد گى اسـتاندارد شده مرديا' و نسبت بحر انى استفاده شده است. بنابر

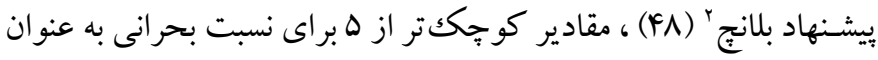
عـدم تخطى از نرمـال بودن جِنـدمتغيره در نظر گرفتـه مىشــود. در اين

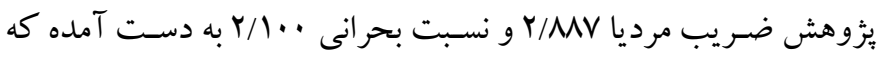
كمتر از عدد ها استـ؛ بنابر اين فرض نرمال بودن جندمتغيرى برقرار است.
1. Mardia standardized kurtosis coefficient

2. Blunch

3. Mahalanobis d-squared method 
جدول "َ: شناسهاى برازش الكوى ييشنهادى، اصلاح شده و الكوى نهايى

\begin{tabular}{|c|c|c|c|c|c|c|c|c|c|c|}
\hline RMSEA & IFI & CFI & PNFI & PCFI & GFI & $\chi^{2} / \mathbf{d f}$ & $\mathbf{P}$ & Df & $\chi^{2}$ & شناسه هاى برازش \\
\hline$\cdot / \cdot v \Delta$ & $\cdot / \wedge \Delta \Lambda$ & $\cdot / \wedge \Delta 4$ & ./or. & $\cdot / \Delta F \Delta$ &.$/ 911$ & $r / r q q$ & $<\cdot / \cdot \cdot 1$ & fr & IrN/DVG & الخوى بيشنهادى \\
\hline .1 .99 & $\cdot / 9 \cdot v$ & $\cdot / 9 \cdot 0$ & $\cdot / \Delta \Delta F$ & $\cdot / \Delta V$ &.$/ 91 r$ & r/VVG & $<\cdot / \cdot \cdot 1$ & FF & IYY/IFV & الكوى اصلاح شده \\
\hline r. & . /QYY & . /aYs & .1914 & $\cdot / 9 \cdot V$ & . /QYV & r/lFr & $<\cdot / . \cdot 1$ & Fi & $\Lambda V / q . r$ & الخُوى نهايى \\
\hline
\end{tabular}

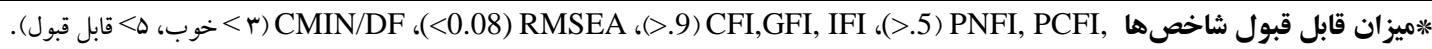

$$
\begin{aligned}
& \text { در جدول F نيز ضرايب استاندارد مسيرها و شكل ا الكوى نهايى بثوهش } \\
& \text { (مدل اصلاح شده) گزارش شده است. }
\end{aligned}
$$

\begin{tabular}{|c|c|c|c|c|}
\hline سطح معنادارى & نسبت بحر انى & خطاى معيار & ضر ايب استاندارد & 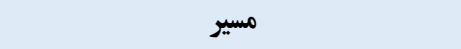 \\
\hline$<\cdot / \cdot \cdot 1$ & $r / r \Delta F$ & $\cdot / \cdot \mathrm{Vr}$ & . rar & باورهاى هوشى_--_> اهداف ييشرفت \\
\hline$<\cdot / \cdot \cdot 1$ & $\Delta /|V|$ & .11 .4 & - TYK & باور هاى هوشى --->> خو دكار آمديندارى \\
\hline$\cdot / \pi r \mid$ & $1 / 1 r$. &.$/ M A F$ &.$/ T r_{F}$ & ->> خودتنظيمى ياد گيرى \\
\hline$<\cdot / \cdot \cdot 1$ & $11 / 9 \cdot v$ &.$/ .94$ & $\cdot / M A$ & باورهاى انكيزشى_-->> اهداف يِيشرفت \\
\hline$<\cdot / \cdot \cdot 1$ & $|r /| F$. &.$/ 1 \mathrm{rq}$ & $\cdot / 1 \cdot 9$ & باورهاى انخيزشى --->> خو كار آمديندارى \\
\hline$\cdot / \cdot 9$ & $r / 9 \cdot \Delta$ & $\cdot / \mathrm{IV}$ & $\cdot 10 \cdot 9$ & باورهاى انخيزشى ---> خود تنظيمى ياد كيرى \\
\hline$\cdot / 9 \cdot r$ & $\cdot /$ r 49 & $\cdot /$ A V & $.1 \cdot 19$ & ادراك از جوّ كلاس--->> هداف بيشرفت \\
\hline$<\cdot / \cdot \cdot 1$ & F/ar. & $\cdot / \mathrm{V} \vee$ & $\cdot / 1 \wedge \Delta$ & ادراكى از جو كلاس --->> خود كار آمديندارى \\
\hline$<\cdot / \cdot 1$ & r/AvG & $\cdot / 110$ & $\cdot /$ r & ادراكى از جو كلاس --->> خودتنظيمى يادگيرى \\
\hline$<\cdot / \cdot 1$ & $1 \cdot / V 99$ &.$/ \% \Delta$ & $\cdot / N r 1$ & اهداف يِشرفت--->> خودتنظيمى يادگيرى \\
\hline.$/ \cdot 14$ & $r / \& V Y$ &.$/ \cdot \Delta$ & $\cdot / 10$ & خود كار آمديندارى--->> خو دتنظيمى يادگيرى \\
\hline
\end{tabular}

جدول ع: ضرايب استاندارد مسيرهاى الكوى نهايى (اصلاح شده)

بيشـرفت رابطه مثبت و معنادار؛ و بين باورهاى هوشى، باورهاى انكيزشى و ادراكك از جوّ كلاس با خود كار آمديندارى رابطه مثبت و معنادار وجود

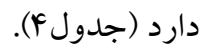

نتـايج حـاصــل از روابط مســتقيم متغيرهـاى بثزوهش در مدل نهايى

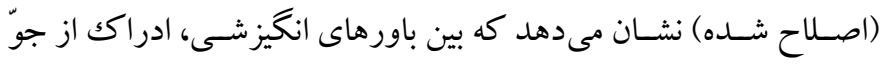
كلاس، اهداف يِيشـرفت، و خود كار آمديندارى با خود تنظيمى ياد گيرى رابطه مثبت و معنادار؛ و بين باورهاى هوشى، باورهاى انگيزشى با اهداف 


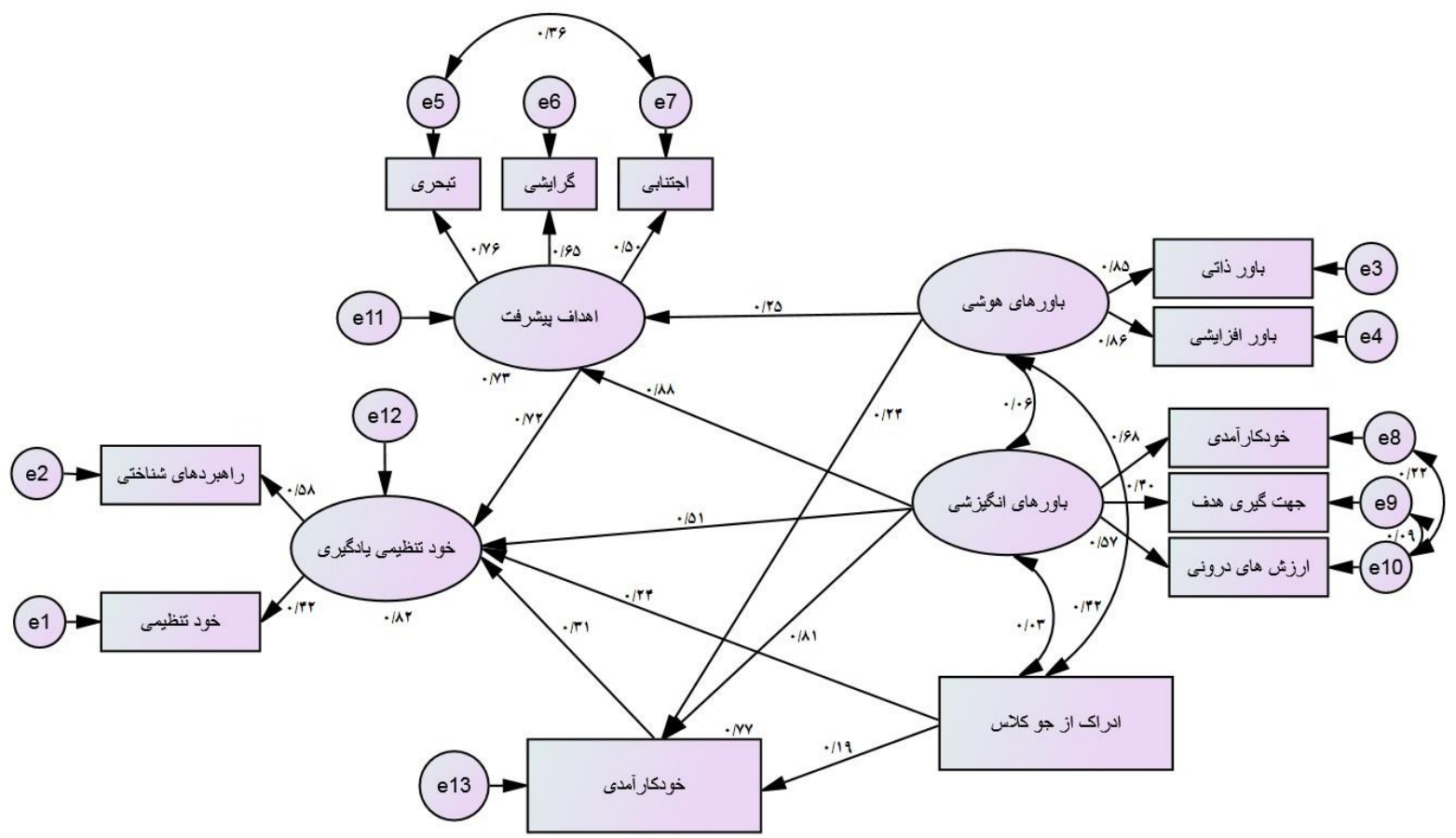

شكل ا: ضرايب استاندارد مدل التوى نهايى (اصلاح شده) رابطه ساختارى باورهاى هوشى، باورهاى انكيزشى، ادراكى از جوّ كلاس با خودتنظيمى يادئيى از طريق

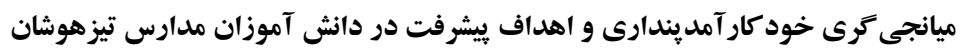

$$
\begin{aligned}
& \text { نتايج حاصل از روابط واسطهاى با استفاده از آزمون بوت استرٍ در } \\
& \text { برنامه MACRO يريجزر و هايز (•ه) به جهت آزمودن مسـير واسطهاى } \\
& \text { در جدول ه نشان داده شده است. }
\end{aligned}
$$

\begin{tabular}{|c|c|c|c|c|c|c|}
\hline 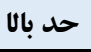 & حد بايين & خطاى معيار & سوكيرى & 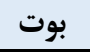 & داده & مسيرها \\
\hline.$/ \cdot$ far & $-\cdot / \cdot 119$ &.$/ \cdot 1 \mathrm{kr}$ & $\cdot / \cdot r 4$ & $.1 \cdot 1149$ & $\cdot / \cdot 1 \cdots$ & باورهاى هوشى † اهداف يِشرفت † خودتنظيمى ياد گيرى \\
\hline$\cdot / \cdot$ rmF &.$- / \cdot \Delta q$. &.$/ . r 9$. & -.1 .94 & $\cdot / \cdot v V^{F}$ & $\cdot / \cdot V F$ & باورهاى هوشى † خود كار آمديندارى † خود تنظيمى ياد گيرى \\
\hline . raqu &.$/ .914$ &.$/$ \&rr & $\cdot / \cdots 1$ &.$/$ rar. &.$/ 4919$ & باورهاى انخيزشى ־ اهداف بيشرفت ־ خودتنظيمى يادگيرى \\
\hline$\cdot /$ IFYA &.$/ \cdot 119$ & 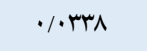 & $\cdot / \cdots r$ & $\cdot / \cdot$ Vre & $\cdot / \cdot V Y F$ & باورهاى انكيزشى ־ خود كار آمديندارى ־ خودتنظيمى ياد گيرى \\
\hline$\cdot / 11 \cdot v$ & $-\cdot / \cdot 499$ & $\cdot / \cdot$ rva & $\cdot / \cdots v$ & $\cdot / \cdot r \cdot v$ & $\cdot / \cdot r \cdot$. & ادراكك از جو كلاس ־ اهداف بيشرفت † خودتنظيمى ياد گيرى \\
\hline$\cdot / r \Delta 99$ &.$/ .9 V \wedge$ & .1 .941 & $\cdot \cdots+1$ & $\cdot / 4194$ & $\cdot / 4190$ & ادراكى از جوّ كلاس ־ خود كار آمديندارى ־ خودتنظيمى يادگيرى \\
\hline
\end{tabular}

جدول 0: آزمون ميانجى كرى روابط غير مستقيم به روش بوت استراب

\section{بحث و نتيجه Fيرى}

يخوهش حاضسر با هدف بررسـى مدل ييشبينى خود تنظيمى ياد گيرى بر

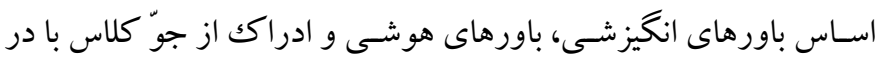

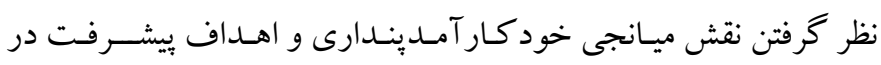
دانش آموزان مدارس تيز هوشـان انجام شـــ. نتايج نشـان داد شـاخص هاى برازش مــدل يثزوهش در وضــيـت مطلوبى قرار دارد. همجينين متغير
نتـايج آزمون بوت اســتربّ نشــان داد كه اثر غيرمســتقيم باورهاى

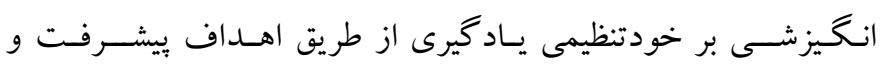

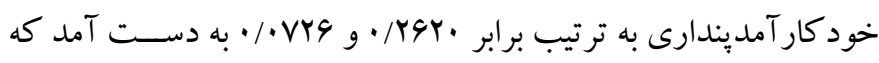
از لحـاظ آمـارى معنـادار بودنـــ. همجينين اثر غيرمســتقيم ادراكك از جوّ كلـاس بر خودتنظيمى يـاد گيرى از طريق خودكـار آمـدينـدارى برابر 1994/ • به دست آمد كه از لحاظ آمارى معنادار بود. 
براى يـاد گيرى و انجام تكليف ارتبـاط دارد. همجنين مؤلفهـ عـاطفه بيان كنتـده واكنش هاى عاطفى و هيجانى دانش آموزان نســبت به انجام يكك

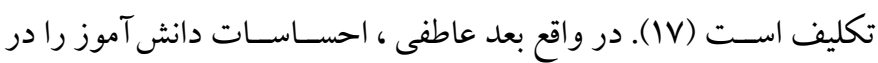

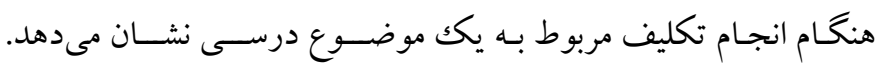

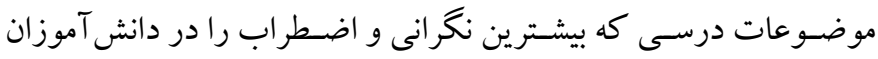

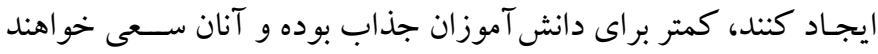

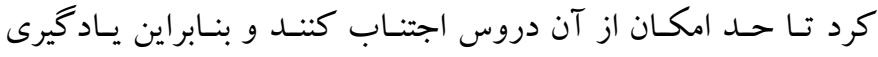

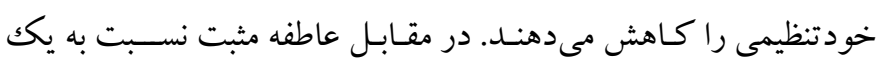

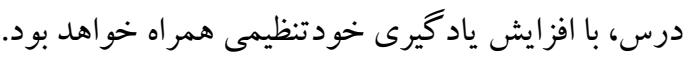

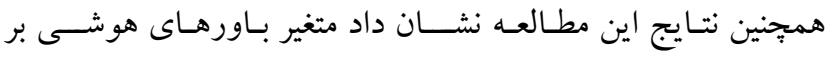

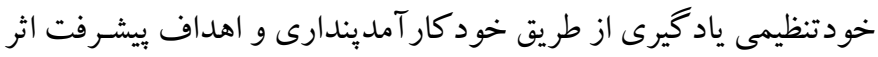

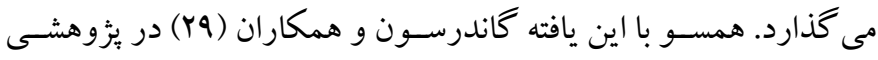

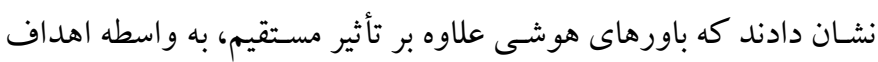

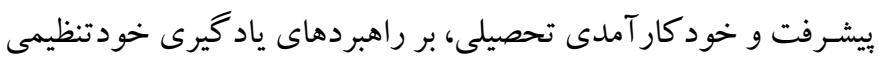

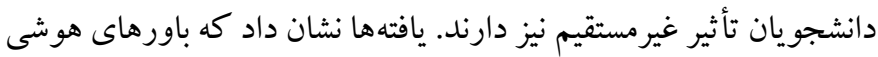
دانشــويان به خصـوص باورهاى هوشـى افزايشسى مى تواند از طريق

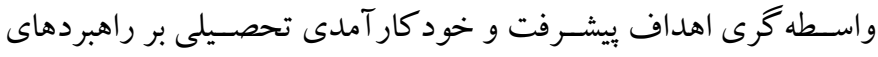

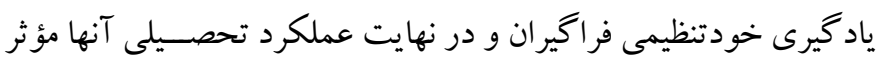

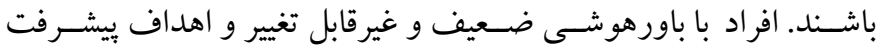

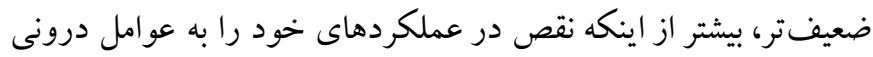
و شـخصى نسـبت دهند، به دليل خطاهاى شـناختى كه دارا هسـتند، ديخران را مشاهده كرانى منتقد تلقى مى كنند كه در يى يافتن ضعفها

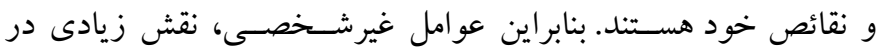

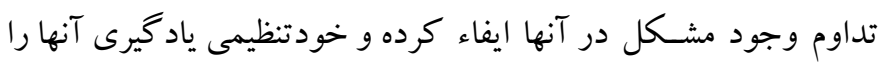
تحت تأثير قرار مىدهد. در مقابل داشتن اهداف مشخص و قابل تحليل و دسـت يافننى همراه مى تو اند در افزايش احسـاس قدرت تأثير بر محيط و

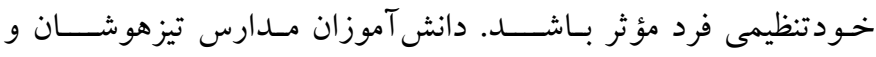

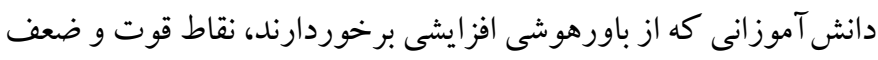

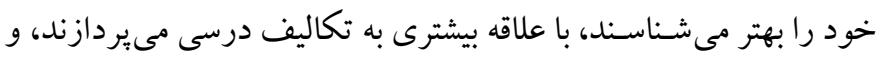

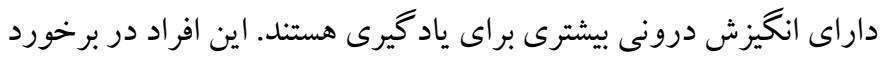

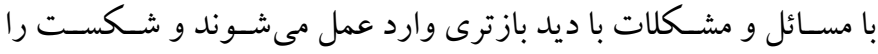
عاملى براى موفقيتهاى بعدى مىدانند و نيز بيشتر روى اهداف ياد گيرى
باورهاى انگيزشى بر متغير خودتنظيمى ياد گيرى هم اثر مستقيم و هم اثر

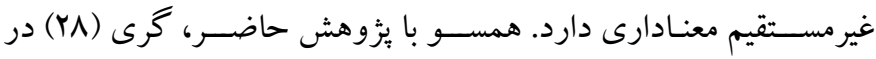

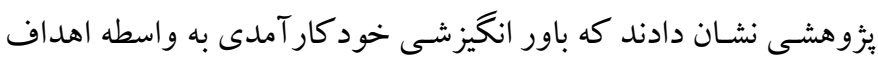

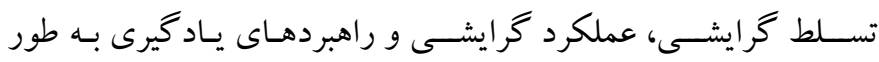
غيرمسـتقيم و مثبت بر ييشـرفت تحصـيلى اثر دارد؛ ولى از طريق هدف

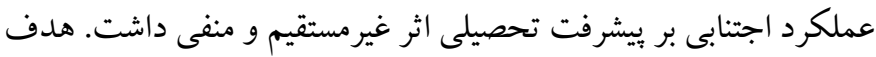

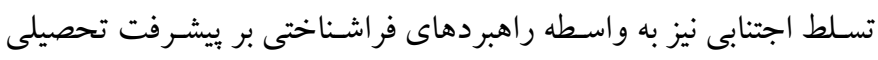

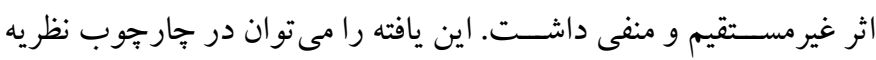

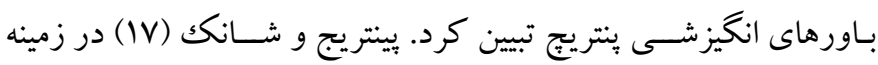

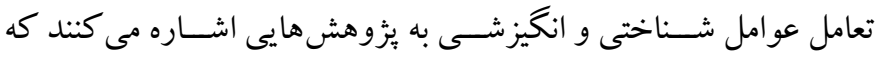

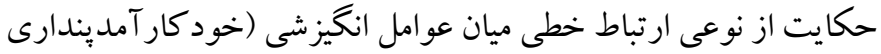

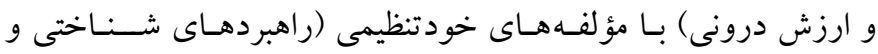

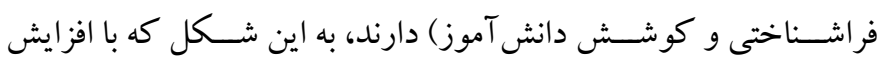

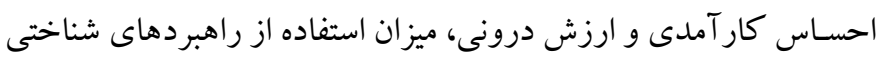

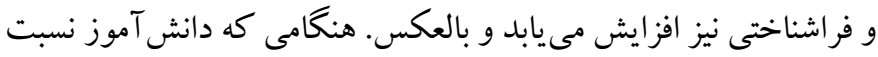

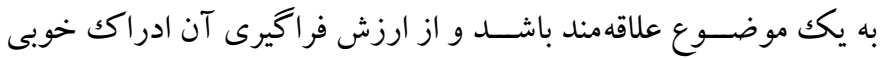
داشـته باشـل، به طور جدى شـايستخى و صلاحيت خود را در آن موضوع

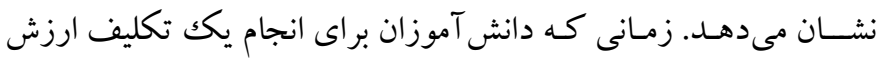

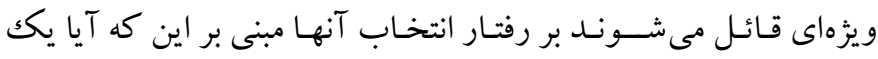

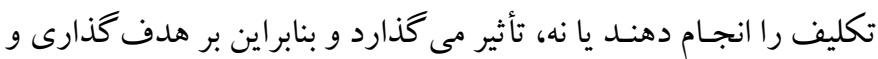
در ادامه خودتنظيمى ياد گيرى آنها اثر مى گذارد. از ســويى مؤلفه انتظار

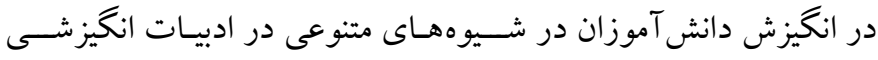

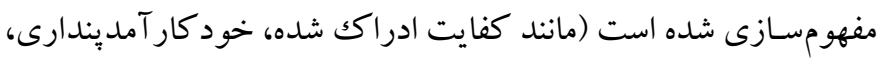
سبكك اسنادى، و عقايد مربوط به مهار گرى)، اما سازه اصلى شامل عقايد

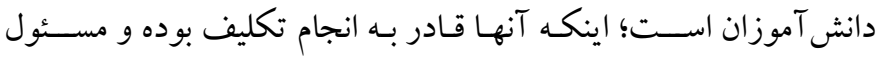
عملكردشـان هستند (IV). همجِنين مؤلفه ارزش شامل اهداف و باورهاى دانش آموزان دربـاره مهم بودن و جـالـب بودن يـك تكليف رد را نشــــان

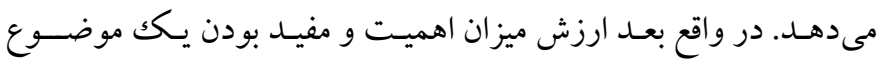
درسى را براى دانش آموزان نشـان مى دهد. موضـوعات درسى كه بيشتر براى دانش آموز مهم، جالب و دوسـت داشـتنى باشـــ، به همان اندازه نيز

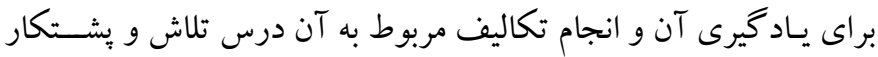
خواهد داشـت. بعد ارزش در انخيزش اسـاسـاً به استـدلالهاى دانش آموز 
اسـتفـاده منـاسـبـ از زمـان آموزش مىشــود. رفتـار اجتمـاعى معلم با

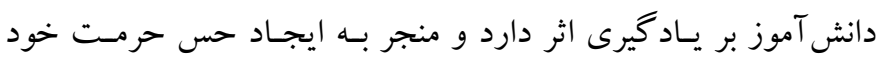

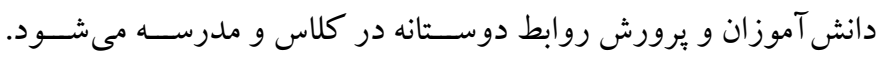

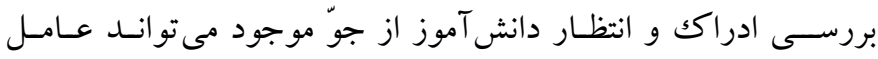

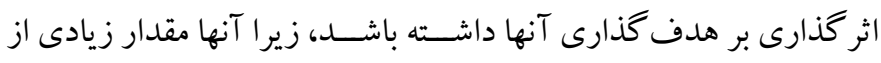

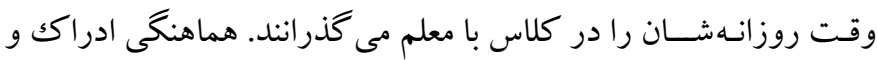

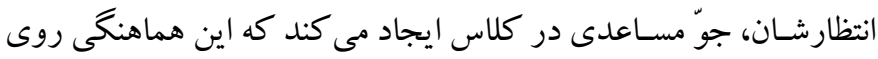

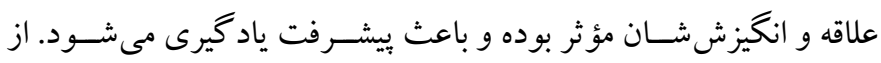

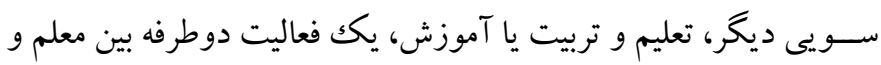
دانش آموزان در كلـاس اســت و اين ارتباط دوجانبه در ايجاد علاقه مهم است؛ بنابراين جوّ روانى اجتماعى كلاس بايد طورى باشد كه باعث علاقه

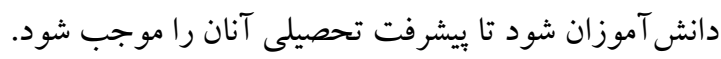

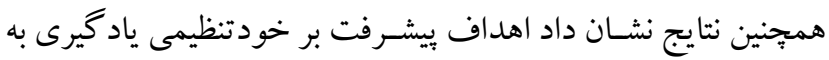

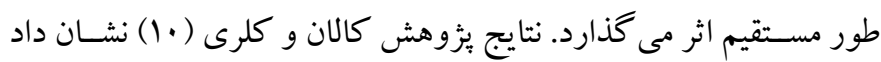

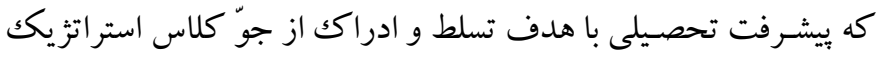
ارتباط مثبت، و با عملكرد اجتناب و ســطح ياد گيرى اسـتر اتزى ارتباط

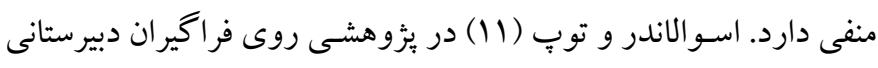

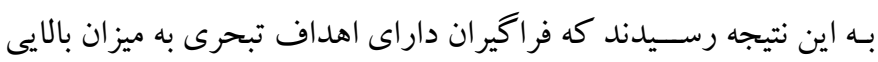

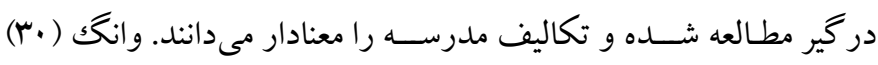
معتقد اسـت كه اهداف تسـلطى با ميانجى گرى در گيرى شناختى و ميزان مدان تلاش صسرف شـده داراى اثر غير مسـتقيم بر بيشـرفت تحصسيلى اسـت.

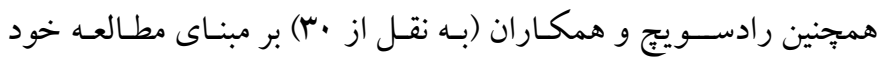

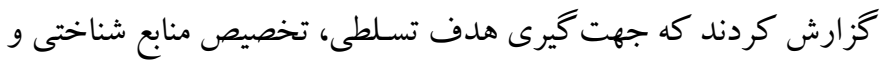

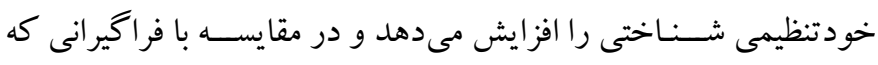
هدف هاى عملكردى دارند افراد تسلطى خودتنظيمى بهتر و لذت شناختى رتى بيشـترى را تجربـه كرده و تنيدگى كمترى دارند. به علاوه دانش آموزان

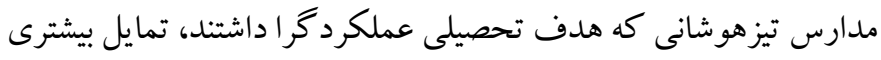

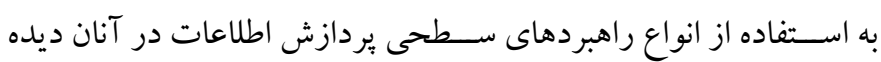

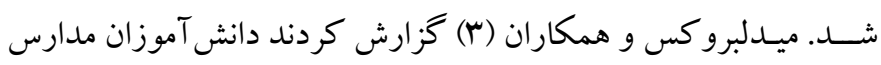

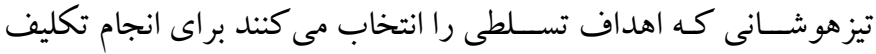

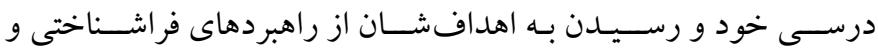

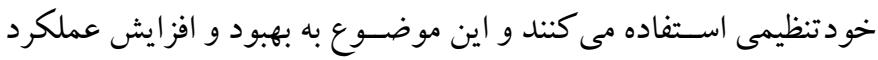

متمر كز مىشـــــــــــا اهــاف عملكرد. اين افراد در زمان امتحان، كمتر دجار اضطراب مى شوند و در نتيجه عملكرد بهترى نيز دارند و در رسيدن

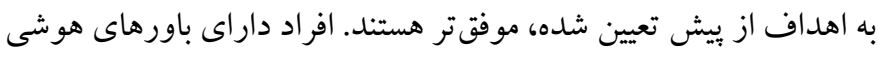

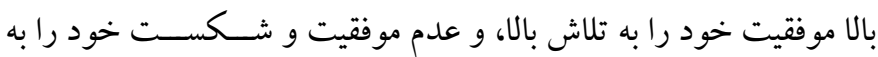

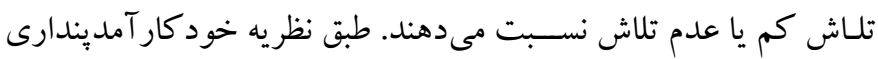

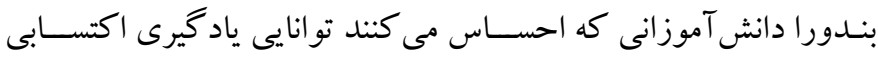

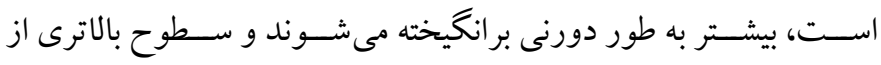

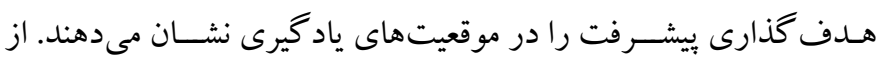

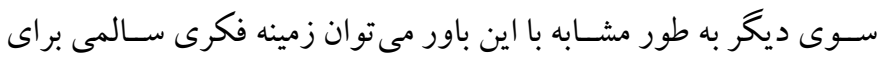

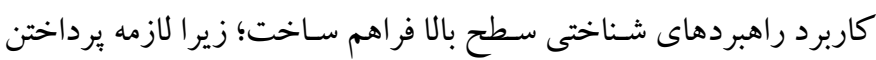

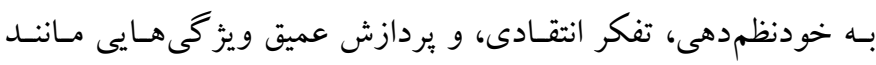

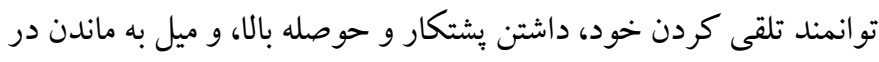

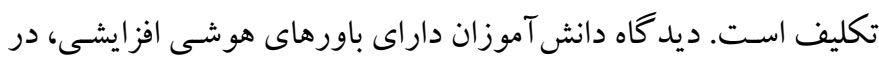

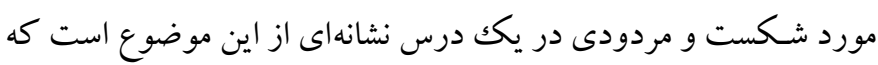

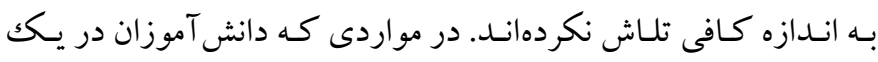

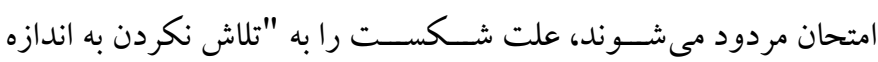

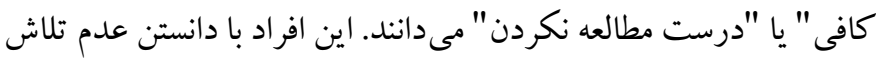

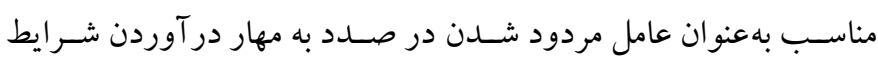

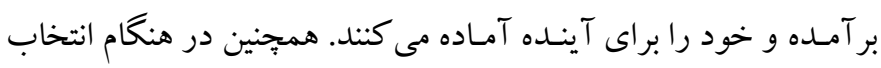

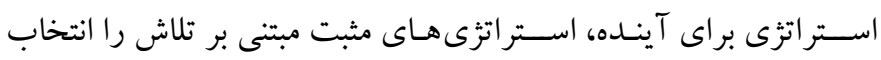

ديخر نتايج اين بثروهش نشان داد ادراكك از جوّ كلاس بر خودتنظيمى ياد گيرى از طريق اهداف ييشـرفت اثر مى گذارد. همسو با اين يافته خحانى

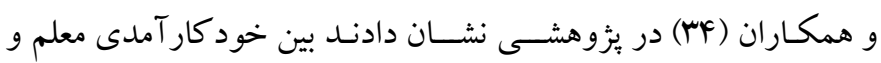

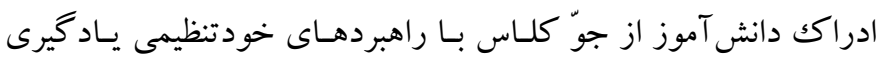
دانش آموزان مـدارس تيزهوشـــان رابطه مثبـت و معنادار وجود دارد. در

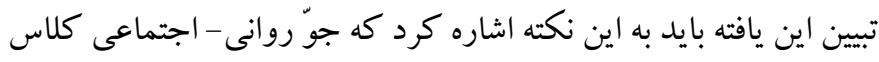

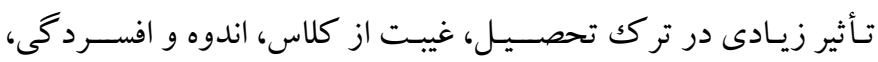

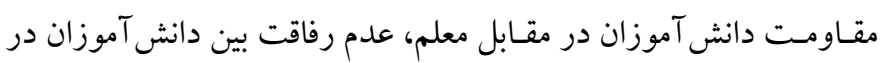

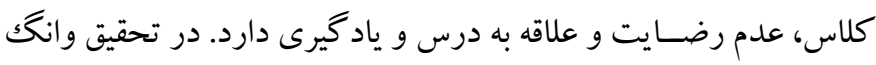

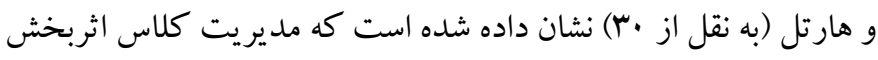

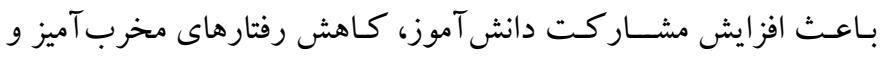


اعلام كند؛ كه دانش آموزان و دانشـويان موفق كسـانى هسـتند كه زمان مـورد نيـاز براى انجـام تكـاليف درس را يِيشبينى مى كنتـد، دربـاره

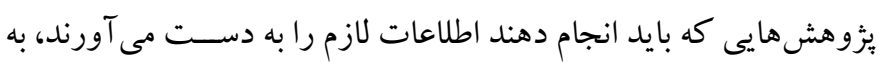

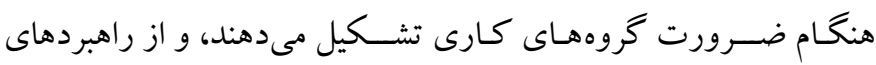

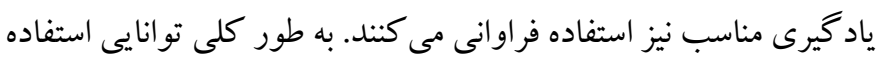

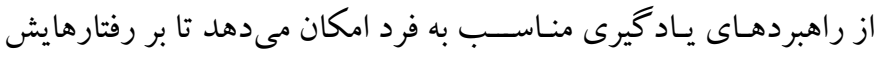

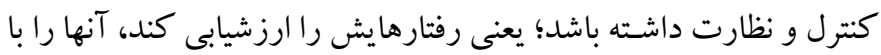
معيار هاى خويش بسـنجد، و در مورد شـخص خود، تقويت و تنبيه اعمال

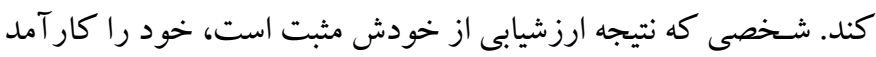

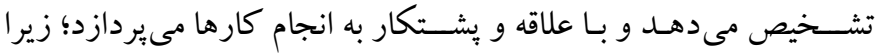

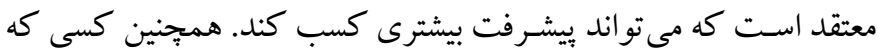

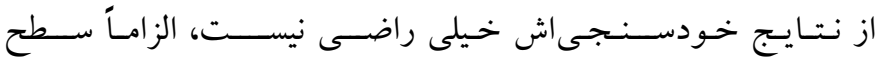

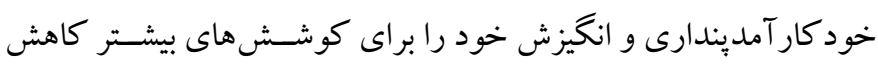

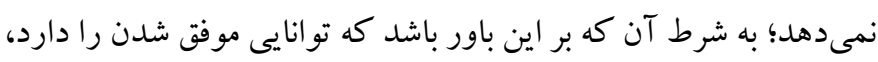
اما روشى كه تاكنون به كار بسته نادرست بوده است. از جمله محدوديت هاى بزُوهش حاضـر مى توان به اين مورد اشـاره

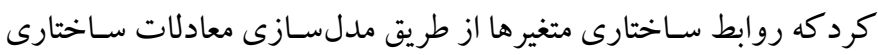

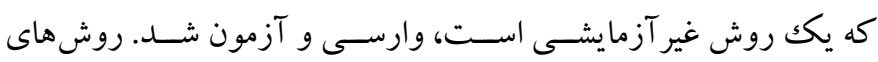

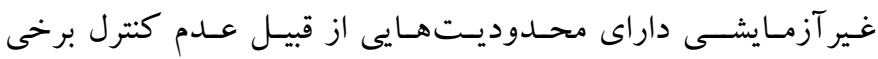

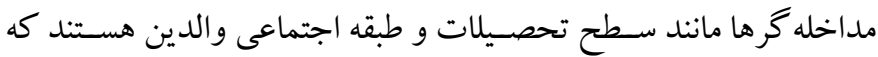

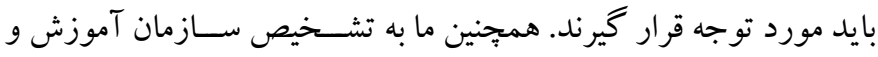

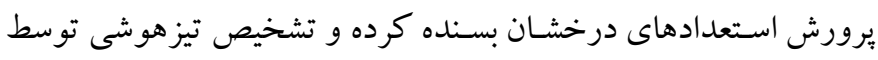

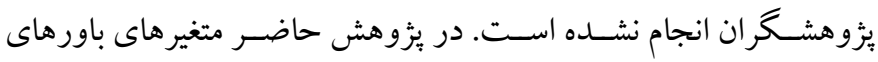

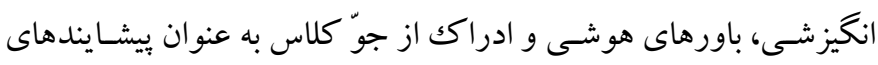

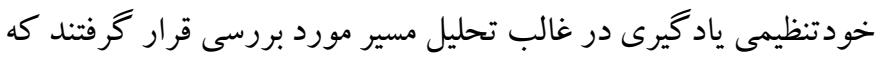

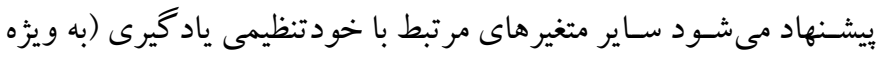

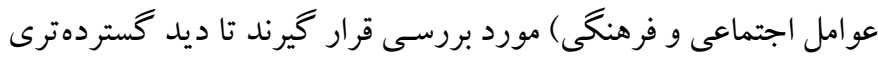

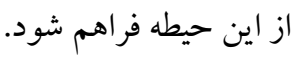

تحصـيلى آنها منجر مىشـود؛ ولى دانش آموزان مدارس تيزهوشـانى كه اهداف عملكردى را انتخاب مى كنند براى انجام تكليف درسـى همواره

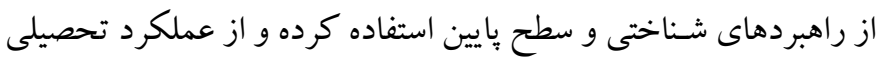

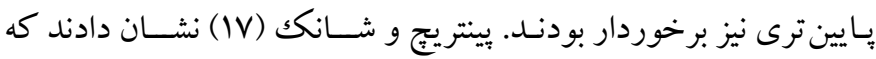

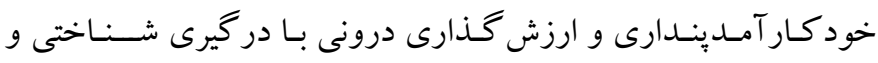
فراشـناختى و عملكرد تحصـيلى رابطه مثبت داشـــه و فراخير ان كه از راهبرد خودنظمدهى استفاده مى كنند، به مر اتب سطح بالاترى از انخيزش

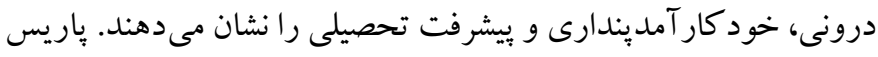

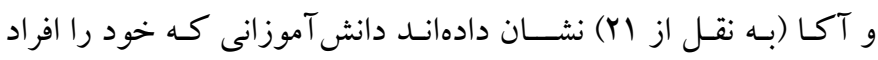

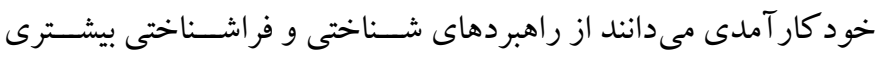

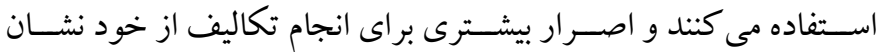
مى دهند. نتـايج اين مطـالعه نشـــان داد خود كـار آمـدينـدارى بر خودتنظيمى

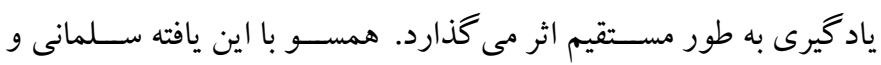

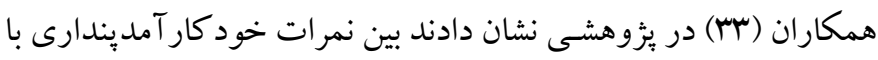
مؤلفـهـاى راهبردهـاى مطـالعه و ياد گيرى و بين مؤلفه هاى راهبردهاى مطالعه و يادگيرى و نيز خود كار آمديندارى با معدل ترم گذشيـته ارتباط

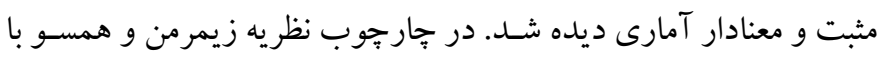

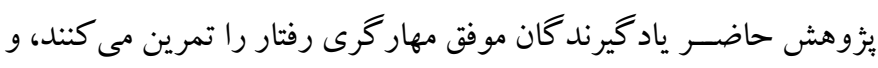

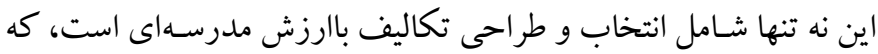

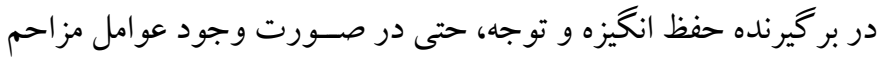
ديخر نيز اسـت. يـادگيرند گان با راهبردهاى يادگيرى مناســب، به طور

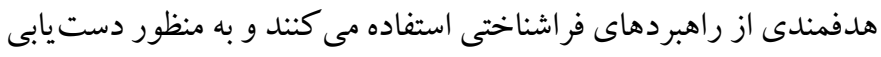

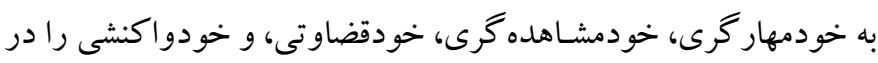
مورد خود ارزيابى مى كنتـد. دمبو (بهـ نقل از الr) درباره اهميت اين نوع

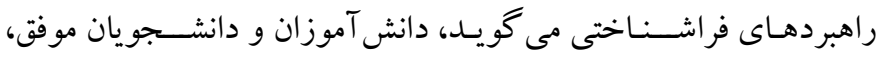

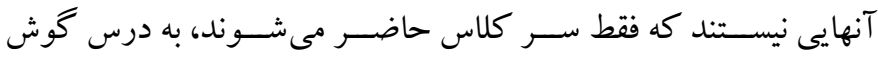

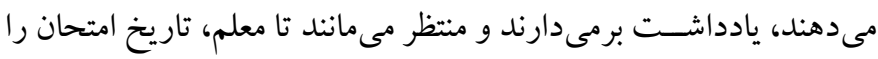


1991 نويسنده نخست اين مقاله به عنوان يثزوهشخر و نويسنده و مابقى نويسند كان اين مقاله در نقش استادان راهنما و مشاور، نقش داشتند. تضـاد منافع: بدين وسيله اعلام مى شود كه اين مطالعه هيج كونه تضاد منافعى را براى نويسند گان به دنبال نداشته است تشكر و قدردانى: بدين وسيله از استادان راهنما و مشاور اين يثزوهش و همجيجين افراد نمونه و از تمامى كسـانى كه ئزوهشـكران را يارى رسـاندند كمال تشـكر و قدردانى را داريم.
ملاحظات اخلاقى ييروى از اصول اخلاق يخوهش: طرح بيشنهادى مطالعه حاضر توسط كميته علمى

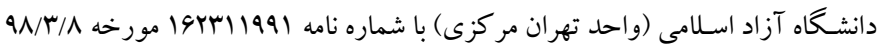
مصوب شد. همجينين اين مطالعه با رضايت كامل افراد نمونه انجام شد. حامى مالى: اين يثزوهش بدون دريافت حمايت مالى از دانشـگاه يا هر گونه سـازمان ديخر و فقط با هزينه هاى شخصى انجام شد. نقش هر يكك از نويسـند Fان: اين مقاله بر كرفته از رسـاله دكترى نويسنده نخست و

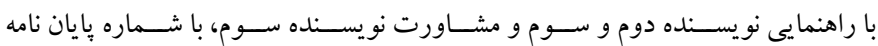




\section{References}

1. Callan GL, Rubenstein LD, Ridgley LM, McCall JR. Measuring self-regulated learningduring creative problem-solving with SRL microanalysis. Psychology of Aesthetics, Creativity, and the Arts. Advance online publication. 2021; 15(1): 135. [Link]

2. Yeo DJ, Fazi LK. The optimal learning strategy depends on learning goals and processes: Retrieval practice versus worked examples. Journal of Educational Psychology 2019; 111(1): 73-90. [Link]

3. Masoumi Jahandizi H, Hejazi M. Evaluation of the status of self-regulatory learning strategies in medical and nursing students of Zanjan University of Medical Sciences in the academic year 2018-19. Journal of Medical Education Development. 2020; 13(38): 7685. [Link]

4. Zimmerman BJ. A Social Cognitive View of Selfregulated Academic Learning. Journal of Educational Psychology. 2008; 81: 329-339. [Link]

5. Schunk DH. Self-efficacy and academic motivation. Educational psychologist. 1991; 26(3-4): 207-231. [Link]

6. Kasalak G, Dagyar M. University Student Satisfaction, Resource Management and Metacognitive Learning Strategies. Teachers and Curriculum. 2020; 20(1): 73-85. [Link]

7. Feral J, Valcke M, Schuyten G. Student model of learning and their impact on study strategies. Journal of Society for Research in Higher Education. 2009; 34: 185-202. [Link]

8. Cho HJ. Levesque-Bristol C, Yough M. International students' self-determined motivation, beliefs about classroom assessment, learning strategies, and academic adjustment in higher education. Higher Education. 2021: 1-21. [Link]

9. Zamakhsari Z, Masruri S, Sutrisno S. Self-Regulatory Learning Patterns of Disabled Students at UIN Sunan Kalijaga Yogyakarta. International Journal of Islamic Educational Psychology. 2020; 1(2): 126-146. [Link]

10. Callan GL, Cleary TJ. Multidimensional assessment of self-regulated learning with middle school math students. School Psychology Quarterly. 2018; 33(1): 103-111. 10. [Link]

11. Swalander L, Taube K. Influences of familybased prerequisites, reading attitude, and self-regulation on reading ability. 2009; 32: 206-230. [Link]

12. Eghbali A, Moghani A. The effectiveness of selfregulated learning based on Pintrich model on problem solving / planning / organizing and behavioralemotional organization of primary school male students with reading disorder in Tabriz. Journal of Modern Psychological Research. 2018; 50: 85-67. [Persian]. [Link]

13. Ariel R., Karpicke JD. Improving selfregulated learning with a retrieval practice intervention. Journal of Experimental Psychology. Applied, 2018; 24(1): 43-56. [Link]

14. Bandura A. Self-efficacy: The exercise of control. New York: Freeman. 1997; 333: 48463. [Link]

15. Aksan N. A descriptive study: epistemological beliefs and self regulated learning. Proc Soc Behav Sci. 2009; 1(1):896-901. [Link]

16. Hope M. O. The impact of peer victimization in high school on first-year undergraduates' psychosocial adjustment and academic performance. The University of Nebraska-Lincoln. 2016. [Link]

17. Pintrich PR, Schunk DH. Motivation in education: Theory, research, and applications. NJ: Prentice- Hall. Inc 2002. [Link]

18. Geitz G, Joosten-ten Brinke D, Kirschner PA. Changing learning behaviour: Self-efficacy and goal orientation in PBL groups in higher education. International Journal of Educational Research. 2016; 75: 146-158. [Link]

19. Domurath A, Coviello N, Patzelt H, Ganal B. New venture adaptation in international markets: A goal orientation theory perspective. Journal of World Business. 2020; 55(1): 101019. [Link]

20. Lin GY. Scripts and mastery goal orientation in faceto-face versus computer-mediated collaborative learning: Influence on performance, affective and motivational outcomes, and social ability. Computers \& Education. 2020; 143: 103691. [Link]

21. Daumiller M, Dickhäuser O, Dresel M. University instructors' achievement goals for teaching. Journal of Educational Psychology. 2019; 111(1): 131. [Link]

22. Islam T, Ahmad S, Kaleem A, Mahmood K. Abusive supervision and knowledge sharing: moderating roles of Islamic work ethic and learning goal orientation. Management Decision 2020. . [Link]

23. Ucar MF, Sungur S. The role of perceived classroom goal structures, self-efficacy, and engagement in student science achievement. Research in Science \& Technological Education. 2017; 35(2): 149-168. [Link]

24. Schneider M, Preckel F. Variables associated with achievement in higher education: A systematic review of meta-analyses. Psychological Bulletin. 2017; 143(6): 565-600. [Link] 
25. Muenks K, Wigfield A, Yang JS, O'Neal CR. How true is grit? Assessing its relations to high school and college students' personality characteristics, selfregulation, engagement, and achievement. Journal of Educational Psychology. 2017; 109(5): 599-620. [Link]

26. Kavita, Kulwinder Singh. Motivational Beliefs and Academic Achievement of University Students. IOSR Journal of Research \& Method in Education. 2014; 4(1): 1-3. [Link]

27. Van Damme J, Maes L, Clays E, Rosiers JF, Van Ha $\mathrm{G}$, Hublet A. Social motives for drinking in students should not be neglected in efforts to decrease problematic drinking. Health education research. 2013; 28(4): 640-650. [Link]

28. Gray D, Chang Y, Anderman EM. Conditional effects of mastery goal structure on changes in students' motivational beliefs: Need for cognition matters. Learning and Individual Differences. 2017; 40: 9-21. [Link]

29. Gunderson EA, Hamdan, Sorhagen NS, D'Esterre AP. Who needs innate ability to succeed in math and literacy? Academic-domain-specific theories of intelligence about peers versus adults. Developmental Psychology. 2017; 53(6): 1188-1205. [Link]

30. Dweck CS, Molden DC. Self-theories: Their impact on competence motivation and acquisition. In A. Elliot, \& C.S. Dweck (Eds.). The handbook of

37. Sherer M, Maddux JE, Mercandante B, Prentice-Dunn S, Jacobs B, Rogers RW. The self-efficacy scale: Construction and validation. Psychological reports. 1982; 51(2): 663-671. [Link]

38. Asgharnejad, T, Ahmadi Dehghotboddini M, Farzad V, Khodabakhshi M. Psychometric Properties of Sherer's General Self-Efficacy Scale. Journal of Psychology. 2006 [cited 2021July25]; $10(3$ (39)):262274. [Persian]. [Link]

39. Midgley C, Kaplan A, Middleton M, Maehr ML, Urdan T, Anderman LH., \& Roeser R. The development and validation of scales assessing students' achievement goal orientations. Contemporary educational psychology, 23(2). 1998: 113-131. [Link]

40. Shirazi M, Marziyeh A, Nazari A. The predictive role of achievement goals and intelligence beliefs associated with assertiveness. Biquarterly Journal of Cognitive Strategies in Learning, 2018: 5(9), 161175. [Link]

41. Pintrich PR, De Groot EV. Motivational and selfregulated learning components of classroom academic performance. Journal of educational psychology. 1990: 82(1), 33. [Link] competence and motivation. New York: Guilford 2005. [Link]

31. Plaks JE, Grant H, Dweck CS. Violations of implicit theories and the sense of prediction and control: Implications for motivated person perception. Journal of Personality and Social Psychology. 2005; 88: 245262 [Link]

32. Dweck CS. Self-theories: Their role in motivation, personality, and development. Psychology press 2000. [Link]

33. Salmani M, Khamsan A, Asadi Younesi MR. The mediating role of motivational beliefs in the perception of classroom atmosphere and students' procrastination. Journal of Educational Psychology. 2016; 43: 169-141. [Persian] [Link]

34. Khani H, Fazeli H, Karimi Y, Bandak M, Prgari N. Assessing the psychosocial atmosphere of the classroom in identifying the internal structure of the school and its relationship with students' creativity. Quarterly Journal of Innovation and Creativity in the Humanities. 2013; 3(10): 19-29. [Persian]. [Link]

35. Scherman A. Factors influencing adolescents' decisions to engage in risk-taking behavior. Adolescence. 2002; 37(147): 585. [Link]

36. Tabachnick BG, Fidell LS. Using multivariate statistics, 5th edn Boston. MA: Allyn and Bacon [Google Scholar]. 2007. [Link]

42. Ostovar S, Abedi MA Comparison of Motivational Beliefs and Self-regulating Learning Strategies among Normal and Probation Students. Journal of Educational Psychology Studies. 2016: 13(24), 1-20. [Link]

43. Rovy B, Essex C. Synchronous and asynchronous communication tools in distance education. TechTrends. 2001; 45, 36-42. [Link]

44. Javadi elmi L, Asadzadeh H. Structural Equation Modeling of Students' academic engagement based on Academic Help-Seeking, Transformational teaching, perceived social support with the Mediation Role of Academic Buoyancy. Quarterly Social Psychology Research. 2020; 10(37): 101-122. [Link]

45. Abd-El-Fattah SM, Yates GC. R. Implicit Theory of Intelligence Scale: Testing for factorial invariance and mean structure. In Australian Association for Research in Education Conference, Adelaide, South Australia 2006, November: (pp. 1-14). [Link]

46. Mohebby Norodaldin vand M, Shahny M, Sharifi $H$. Investigating the Psychometric Properties of Implicit Theory of Intelligence Scale (ITIS) in a Student Society. Quarterly of Educational Measurement. 2013; 4(14): 43-64. [Link] 
47. Kline RB. (2011). Principles and practice of structural equation modeling. Second Edition, New York: The Guilford Press. [Link]

48. Blunch N. Introduction to structural equation modeling using IBM SPSS statistics and AMOS. 2012. Sage (2th ed., pp. 24-32). [Link]
49. Chin WW. The partial least squares approach to structural equation modeling. Modern methods for business research. 1998; 295(2): 295-336. [Link]

50. Hayes AF. Introduction to mediation, moderation, and conditional process analysis. Journal of Educational Measurement. 2013; 51(3):335-37. [Link] 